\title{
Earnings forecasts of female CEOs: quality and consequences
}

\author{
Claude Francoeur ${ }^{1} \cdot{\text { Yuntian } \mathrm{Li}^{1} \cdot \text { Zvi Singer }^{1} \text { (D) Jing Zhang }}^{2}$
}

Accepted: 27 December 2021/Published online: 12 January 2022

(C) The Author(s) 2022

\begin{abstract}
This study examines the voluntary disclosure of earnings forecasts by female CEOs. We find that in the backdrop of increased pressure to perform from investors and other stakeholders, female CEOs tend to issue more earnings forecasts than male CEOs, and those forecasts are more accurate. We also find that while financial analysts generally prefer to follow companies headed by male CEOs, female CEOs' efforts to issue accurate earnings forecasts pay off, as these efforts help them close the analyst coverage gap. We provide complementary evidence on the disclosure efforts of female CEOs with regard to updates to the forecast and the $10-\mathrm{K}$ report. Lastly, we show that financial analysts rely more on the earnings forecasts of female CEOs, possibly because they recognize female CEOs' superior forecasting quality. Our results are robust to the use of alternative research designs, including difference-in-difference, propensity score matching, and entropy balancing. Overall, our study documents gender differences in voluntary disclosure by senior management.
\end{abstract}

Keywords Female CEO · Voluntary disclosure · Management forecast · Management forecast errors · Analyst following · Analyst forecasts

JEL D22 $\cdot \mathrm{G} 17 \cdot \mathrm{M} 14 \cdot \mathrm{M} 41$

We appreciate the very valuable comments we received from seminar participants at HEC Paris and McGill University and conference participants at the CAAA annual meeting.

\author{
Zvi Singer \\ zvi.singer@hec.ca \\ Claude Francoeur \\ claude.francoeur@hec.ca \\ Yuntian Li \\ yuntian.li@hec.ca \\ Jing Zhang \\ jing.2.zhang@ucdenver.edu
}

Extended author information available on the last page of the article 


\section{Introduction}

Even though the number of female executives has risen in recent decades, women are still vastly underrepresented among top executives. According to the annual Women CEO report released by Gray and Christmas, Inc (2019), the share of women in new CEO appointments in U.S.-based companies was merely $18.4 \%$ in 2017 . The gender gap in the largest companies is even wider, with women accounting for only $5.4 \%$ of CEOs in S\&P 500 companies (Pew Research Center 2018).

This pronounced gender gap in top management has garnered the attention of researchers. A growing collection of work reports that female executives make a positive impact on firm performance. Female executives enhance firm innovation and create a collaborative work environment (Gaughan and Smith 2016). They also exhibit less overconfidence, i.e., they show better judgment when making important corporate decisions, compared to men (Huang and Kisgen 2013). With respect to financial reporting, companies led by female executives engage less in earnings management (Barua et al. 2010; Gull et al. 2017) and are more conservative in their accounting choices (Francis et al. 2015), probably because women are, on average, more ethical, more risk averse, and less aggressive than men (Valentine and Rittenburg 2004; Lund 2008; Ho et al. 2015). Partly due to these distinctive traits attributed to women, researchers, activists, and regulators are calling for more female representation in top management (e.g., Dezsö and Ross 2012; Habib and Hossain 2013).

In this study, we examine the voluntary disclosure of management earnings forecasts by female CEOs. Management earnings forecasts play a key role in companies' information environment (Hirst et al. 2008) by representing a major channel through which firms communicate voluntary information to their stakeholders (Hilary and Hsu 2011), which has been shown to lead to capital market benefits (Baginski and Rakow 2012; Cao et al. 2017). This type of disclosure can be an ideal means for female CEOs to establish their reputation. More specifically, we examine two important aspects of earnings forecasts issued by female CEOs, compared to their male counterparts: 1) the relative likelihood of issuing a forecast, and 2) the relative accuracy of the forecast.

We expect important differences between the earnings forecasts of male and female CEOs for several reasons. First, important actors in the corporate world (such as investors and board members) are known to hold prejudicial views toward female CEOs (Eagly and Karau 2002; Atkinson et al. 2003; Lee and James 2007; Bøhren and Strøm 2010; NiessenRuenzi and Ruenzi 2019). Male senior managers may also develop negative attitudes toward female CEOs and, as a result, may cooperate less with them (McDonald et al. 2018). Perceiving this prejudice, female CEOs may respond by extending efforts to demonstrate their competency. Issuing accurate management forecasts can be a good way for female CEOs to counter negative attitudes toward them. Doing so can help them establish their leadership at their companies and among other senior managers.

Second, female CEOs are a minority in top management at large public companies, so they face greater scrutiny. According to the well-known theory of tokenism (Kanter 1977), minority groups such as women are subjected to greater pressure to perform. Female CEOs also face greater media scrutiny. For instance, female CEO appointments attract three times as much media attention as male CEO appointments (Gaughan and Smith 2016). Female CEOs can use management forecasts as a way to respond to this pressure. 
Third, inherent gender characteristics and leadership style differences between men and women may lead male and female CEOs to use earnings forecasts differently. Women are known to be more risk averse (Croson and Gneezy 2009), more conservative (Ho et al. 2015), and more ethical than men (Weeks et al. 1999; Valentine and Rittenburg 2004; Lund 2008). Therefore, they may choose to issue earnings forecasts with a higher degree of accuracy in order to minimize risk and conform to ethical standards. Female CEOs are also more willing to communicate (Rosener 1990) and are more relationship oriented (Helgesen 1990). As a result, their interactive leadership style may improve corporate disclosure transparency. For all of these reasons, we expect female CEOs to be associated with a higher likelihood of issuing earnings forecasts, and with more frequent and more accurate earnings forecasts.

On the other hand, there are several reasons why we may not observe differences in management forecast behavior across genders. First, women are promoted mostly by men (Oakley 2000) in a male-dominated environment. Thus, women who were able to break through the glass ceiling and obtain leadership positions may behave in ways that are very similar to men, insomuch as they blend in with their male counterparts (Branson 2006; Adams and Funk 2012). Even if they initially differ from men, female CEOs may decide to adapt their leadership style to conform to masculine norms (Offermann and Beil 1992). This adaptation could contribute to minimizing gender differences among CEOs. Indeed, even though women are generally more risk averse than men (Croson and Gneezy 2009), Adams and Funk (2012) find that female directors are not more risk averse than male directors. Second, CEOs, regardless of their gender, are expected to maximize shareholders' value and lead the organization to success. To succeed, CEOs must make rational and objective value-maximizing decisions. If both male and female CEOs use an objective cost-benefit analysis regarding the issuance of a management forecast, it is unlikely that there will be any gender difference in the likelihood of issuing earnings forecasts or in the forecasts' properties.

Using a sample of U.S. public companies over the period from 2000 to 2018 and a research design with firm and year fixed effects, we find evidence that corroborates our predictions. Specifically, our findings show that female CEOs are $15.3 \%$ more likely to issue management forecasts than male CEOs, and that these forecasts are almost $40 \%$ more accurate.

Next, we examine whether the greater efforts that female CEOs put into forecasting earnings are rewarded by greater analyst following. This is important because an increase in analyst coverage is known to be associated with a positive investor reaction, a decrease in the cost of capital, and a faster incorporation of new information into stock prices (Irvine 2003; Chan and Hameed 2006; Derrien and Kecskés 2013). We expect female CEOs' greater efforts in forecasting earnings to lead to an increase in analyst following because analysts greatly benefit from more accurate management disclosure (e.g., Mikhail et al. 1999; Hong and Kubik 2003; Boivie et al. 2016). We observe that, in general, more financial analysts follow companies led by male CEOs. However, this gap disappears for female CEOs who provide more accurate earnings forecasts; thus, their efforts seem to pay off.

In supplementary analyses, we provide further evidence of female CEOs' greater efforts to address the needs of financial information users. We show that female CEOs provide more frequent earnings forecast updates and continue them later in the year. Female CEOs also provide 10-K disclosures that are longer, contain more visual data, 
and use more unique words. In addition, we examine whether financial analysts recognize the higher-quality forecasts made by female CEOs and, consequently, whether these analysts are more likely to rely on these forecasts. Consistent with analysts recognizing the superior forecasts of female CEOs, we find that analyst forecast errors and analyst forecast dispersion are more sensitive to the management forecast errors of female CEOs than to those of male CEOs.

We conduct various tests to address the potential endogeneity problems of reverse causality and omitted correlated variables. First, we use a difference-in-difference approach in which we identify CEO transitions from male to female (treatment group) and CEO transitions from male to male (control group). We find that the likelihood of issuing an earnings forecast and the earnings forecast accuracy both increase significantly for the treatment group after the transition, compared to the control group. Second, we use propensity-score matching (PSM) and entropy-balancing methods to increase the comparability between companies with female CEOs and companies with male CEOs, and our results continue to hold. Third, we do not find any difference between male and female CEOs regarding the likelihood of beating their forecasts. This rules out the possibility that male CEOs strategically choose to under-forecast in order to increase the likelihood of beating their forecasts, which would make their forecasts less accurate. Fourth, because CFOs are also known to affect earnings forecasts (Bamber et al. 2010), we control for CFO gender and obtain similar results. Using the first (instead of the last) management forecast for a given prediction does not alter our results. Finally, the CEOs of struggling companies, regardless of their gender, may work harder to gain the attention and trust of analysts and investors by providing earnings forecasts with high accuracy. If female CEOs are more likely to be selected to run these "sinking ships" (also known as the "glass cliff" hypothesis, e.g., Ryan and Haslam 2007; Cook and Glass 2014), and if the CEOs of sinking ships make greater efforts to provide high-quality earnings forecasts, then the better earnings forecasts of female CEOs could be due to the types of companies they lead rather than to female CEOs' greater efforts. We compare the performance of companies prior to the appointments of female CEOs and male CEOs and fail to find evidence that the female CEOs in our sample are more likely to run sinking ships.

A concurrent paper by Cook et al. (2020) also examines some aspects of management forecasts by female CEOs. The common aspect of the two studies involves an examination of gender differences in the likelihood of issuing earnings forecasts. However, beyond that point, the two studies take different directions. Cook et al. (2020) mostly argue that differences between males and females in innate personality traits such as overconfidence, narcissism, and risk taking affect the forecast properties of the two genders. Accordingly, they hypothesize that the forecast precision and bias of male and female CEOs will differ, ${ }^{1}$ but they fail to find evidence of this. Neither of these properties concerns the accuracy of the CEOs' forecasts. ${ }^{2} \mathrm{We}$, on the other hand, argue that due to heightened pressure to perform, female CEOs put greater efforts into their forecasts, resulting in greater forecast accuracy. Consistent with our prediction of greater efforts, we find evidence that the forecasts of

\footnotetext{
${ }^{1}$ Forecast precision refers to the forecast range, where a forecast of earnings per share ranging between 0.74 to 0.76 cents is considered more precise than a forecast of earnings per share ranging between 0.72 to 0.78 cents. Forecast accuracy refers to the absolute difference between the forecasted and actual earnings.

${ }^{2}$ Precision is an ex ante measure and therefore is unrelated to the forecast's accuracy. Moreover, a measure of bias might not capture accuracy. Forecasts can be very different than the actuals, but if they are overoptimistic in 50\% of the cases and over-pessimistic in 50\% of the cases, they will be unbiased yet inaccurate.
} 
female CEOs are more accurate and more frequently updated. Because our sample is larger, ${ }^{3}$ we replicate Cook et al.'s tests of gender differences in forecast precision and bias. Similar to Cook et al. (2020), we do not find significant gender differences in those dimensions of the forecast (untabulated). This finding suggests that forecast accuracy is different from forecast precision and forecast bias. As a further divergence, we focus on the consequences of the female CEOs' higher forecast quality. We find that female CEOs who provide more accurate forecasts are able to eliminate the gender gap in analyst following. This finding shows that the female CEOs' greater efforts to provide higher-quality forecasts pay off. Cook et al. (2020), on the other hand, show that investors and analysts hold a bias against female CEOs, but they remain silent on whether and how female CEOs make efforts to reduce it. Overall, we believe our study is comprehensive, consistent, and insightful regarding the greater efforts that female CEOs put into their earnings forecasts, and the benefits of their forecasting efforts.

Our study contributes to the literature in three ways. First, until recently, the literature has paid very little attention to gender differences in voluntary disclosure in general, and in management earnings forecasts in particular. The very few studies on this topic mostly examine small samples outside the United States. ${ }^{4}$ Our examinations of the decision to issue management forecasts, the accuracy of the forecasts, and the forecasts' impact on analyst coverage fill this gap in the literature. We provide consistent evidence of a gender difference between female and male CEOs. We show that companies led by female CEOs are more likely to issue earnings forecasts and provide more frequent forecasts; further, those forecasts are on average more accurate. Second, we contribute to the literature on how female leadership affects corporate behavior (Barua et al. 2010; Francis et al. 2015; Gaughan and Smith 2016; Gull et al. 2017). We argue that female CEOs put more efforts into issuing more frequent and accurate corporate voluntary disclosures, and that male CEOs can learn from this "feminine" leadership style. Third, our study contributes to the literature on gender perception and gender bias and how to mitigate both. We show that women can successfully correct perceptual biases through the provision of high-quality earnings forecasts, leading to a reduced preference, among financial analysts, to follow companies led by male CEOs.

The remainder of the paper is structured as follows. We review the literature and develop our hypotheses in section 2 . In section 3, we describe the research design and sample formation and provide descriptive statistics. Section 4 reports the main empirical results. The results of the supplementary analyses and robustness tests are presented in section 5. The final section summarizes and concludes this study.

\section{Prior literature and hypothesis development}

Various studies have explored the benefits of improving female representation in upper-level management and boards of directors (e.g., Francoeur et al. 2008; Harjoto

\footnotetext{
${ }^{3}$ We collect data from both the Execucomp and Boardex databases, whereas Cook et al. (2020) only use data from Execucomp.

${ }^{4}$ Nalikka (2009) examines a sample of 108 Finnish companies; Alqatamin et al. (2017) examine a sample of 201 Jordanian companies; and Lonkani (2019) examines a sample of 930 observations from Thailand.
} 
et al. 2015; Isidro and Sobral 2015). Their findings increase the legitimacy of hiring women as top executives, and numerous countries (e.g., Norway, Iceland, Spain, and France) and the state of California have introduced legally binding measures to force corporations to nominate more female directors. ${ }^{5}$

Investors have been shown to hold stereotypical views toward, and prejudicial bias against, women in leadership positions (Eagly and Karau 2002; Dobbin and Jung 2010). In line with this tendency to categorize women leaders, Lee and James (2007) find that the stock market reacts negatively to the appointment of female CEOs, and Bøhren and Strøm (2010) report a negative shareholder reaction to an increase in female board representation. Similarly, Jeong and Harrison (2017) report that female representation in the upper echelons is negatively related to short-term stock market returns, even though such representation is positively related to long-term stock performance. In addition, Atkinson et al. (2003) and Niessen-Ruenzi and Ruenzi (2019) report that even though female mutual fund managers do not underperform relative to male mutual fund managers, investors are less likely to invest in their funds. A recent experimental study by Bloomfield et al. (2021) demonstrates that even highly experienced professional investors may hold biased views toward women. The authors show that the professional investors consider female analysts to be less promotable to senior positions, compared with identical male analysts. ${ }^{6}$ Against this backdrop of a negative market bias against women in senior positions, new female CEOs start off their tenure in a disadvantageous position, compared with male CEOs.

In addition to investors' unfavorable attitudes, female CEOs face greater scrutiny from the media and their colleagues inside their organizations. Research on media coverage shows that female CEOs receive greater media attention due to their gender. Lee and James (2007) find that gender is frequently highlighted in the announcements of female CEO appointments but rarely mentioned in announcements involving men. In addition, Gaughan and Smith (2016) find that, compared with male CEO appointments, female CEO appointments attract three times more media attention. Under this higher public exposure, female CEOs' performance during their tenure may have a larger influence on their reputation and their careers. Female executives are a numerical minority in top management. According to the theory of tokenism (Kanter 1977), minority individuals have higher visibility, are subjected to greater performance pressure, and face a less cooperative environment overall. McDonald et al. (2018) find that in the presence of a female CEO, white male senior executives tend to develop a diminished sense of organizational identity and consequently provide less help to the CEO. Studies show that even subordinates will subject minorities to hostility, resistance, and dislike (Nesbitt 1997; Heilman et al. 2004). To be recognized as strong achievers, women must be better qualified and demonstrate outstanding performance as

\footnotetext{
${ }^{5}$ Other states are also taking steps to increase female representation on boards of directors. Colorado has passed a joint non-binding resolution for a minimum number of female directors on the board, depending on the board's size. Maryland and Illinois have passed laws focusing on the disclosure of female representation on the board, and Hawaii, Massachusetts, Michigan, New Jersey, and Washington are each considering mandatory board diversity legislation (Hutcher and Latham 2020).

${ }^{6}$ The authors created a scenario that manipulated whether a male or female analyst who is being considered for a promotion persists in pitching a stock pick that has been voted down by a portfolio manager. The professional investors considered negative (less promotable) analysts that did not persist in pitching the stock, but only if they were female analysts. The authors attribute this gender-based evaluation to categorizing theory, which suggests that evaluators rely on stereotypes when assessing behavior.
} 
top executives. As discussed in Eagly and Carli (2003), female leaders suffer from prejudice in masculine organizational contexts. Moreover, female leaders must be extremely competent to cope. Female CEOs also bear a higher risk of being dismissed (Gupta et al. 2018). Cook and Glass (2014) find that minority CEOs tend to be replaced by white men when firm performance declines. Another source of scrutiny derives from the fact that some companies may appoint women to senior positions for the sake of improving their corporate social responsibility (CSR) index score (Cook and Glass 2018). ${ }^{7}$ These situations may cast doubt on the competency of women and may pressure female executives to prove themselves.

Therefore, in the environment where they operate, female CEOs may feel greater pressure to deliver strong performance and build their reputation. As a result, they are likely to make greater efforts than male CEOs to improve investors' attitudes, gain market participants' confidence, and earn managers' and employees' trust. Previous literature documents various ways to alter investors' perceptions and ultimately increase firm market value (e.g., Cohen and Dean 2005). One reliable way is by increasing voluntary disclosures and financial transparency. For instance, Kimbrough and Louis (2011) find that the market reacts more favorably to the merger announcements of companies holding conference calls. Field et al. (2005) find that preemptive bad-news forecasts help deter substantive lawsuits. Within this context, we investigate the relationship between CEO gender and corporate voluntary disclosure in the form of earnings forecasts. ${ }^{8}$

Earnings forecasts represent the manager's expectations of near-future profitability. Because managers have access to private information, their forecasts of future earnings send a valuable signal to outsiders, notably to investors (Patell 1976; Penman 1980; Nagar et al. 2003; Hilary and Hsu 2011). Management forecasts also guide analysts in preparing their own forecasts (Graham et al. 2005). The manager's decision to provide earnings forecasts depends on the benefits and costs of doing so. Managers issue earnings forecasts when the benefits exceed the costs. On the benefit side, earnings forecasts provide value-relevant input for analysts' forecasts, which can ease the analysts' job and make their forecasts more accurate and less dispersed (e.g., Hassell et al. 1988). These forecasts will increase analyst coverage, reduce estimation risk and information asymmetry, and lower the cost of capital (Lang and Lundholm 1996). On the cost side, once the issuance of earnings forecasts begins, investors expect managers to maintain the practice; companies that stop providing earnings forecasts are likely to be punished by investors (Graham et al. 2005). Furthermore, when actual earnings are less than what was forecasted, companies risk a decline in their stock price.

Meeting investors' and analysts' information needs is important to all CEOs. ${ }^{9}$ However, we see two reasons why issuing earnings forecasts could be more important for female CEOs. First, forecast issuance can help female CEOs build a reputation for transparent reporting (Hirst et al. 2008), which could help them gain investors' and

\footnotetext{
${ }^{7}$ In a survey of board members by Heidrick and Struggles (2012), 32\% of female board members indicated that their gender was a significant factor in their appointment to the board; only $2 \%$ of male directors made a similar claim.

${ }^{8} \mathrm{Ng}$ et al. (2013) show that the market reacts more strongly to more credible management forecasts, suggesting that the market appreciates higher managerial efforts to predict earnings.

${ }^{9}$ Even though CEOs do not directly prepare forecasts, they are likely to be heavily involved in the process (Cheng and Lo 2006; Bolliger and Kast 2007; Baik et al. 2011).
} 
other stakeholders' confidence and lower the level of scrutiny they deal with. Second, some characteristics that are more common for women than men also increase the likelihood that female CEOs issue earnings forecasts. Relative to men, women are, on average, more risk averse (Croson and Gneezy 2009) and more conservative (Ho et al. 2015) and have greater ethical values (Weeks et al. 1999; Valentine and Kidwell 2008). These behavioral traits are bound to extend to how female CEOs lead their organizations. In this regard, Barua et al. (2010) and Gull et al. (2017) find that companies led by female executives engage less in earnings management. Furthermore, Francis et al. (2015) find that companies led by female executives make more conservative accounting choices. We therefore expect female CEOs to report more transparently, as more transparency reduces litigation risk (Field et al. 2005; Hilary et al. 2014) and is considered more ethical. Women also differ from men in their leadership style. It has been established that female CEOs are more willing to communicate (Rosener 1990; Francis et al. 2021) and more relationship oriented (Helgesen 1990). Their more interactive leadership style could improve corporate disclosure transparency, including earnings forecasts.

On the other hand, there are two main reasons why female CEOs may not differ from male CEOs in the likelihood of issuing management forecasts. First, female CEOs are appointed in a mostly male-dominated environment (Oakley 2000). Thus, women who have broken through the glass ceiling and reached the executive suite may behave in ways similar to men (Branson 2006; Adams and Funk 2012). They may even believe that their promotion is greatly due to their similarities with men. Second, if the decision to issue a management forecast is solely based on an organizational cost-benefit analysis, there is no reason to expect female CEOs to behave differently from male CEOs. Nonetheless, we expect women in top leadership positions to be more likely to issue earnings forecasts to ease the great pressure they face. Therefore, our first hypothesis regarding gender differences in issuing earnings forecasts is as follows:

HYPOTHESIS 1: Female CEOs are more likely than male CEOs to issue earnings forecasts.

Our second hypothesis concerns the relative accuracy of earnings forecasts by female CEOs. As discussed above, female CEOs are under pressure to build their reputation and change the way they are perceived. Female CEOs can use the accuracy of their earnings forecasts to signal their competency (Baik et al. 2011). Forecast accuracy signals the manager's capacity to process information (Tan et al. 2002) and is associated with a lower likelihood of CEO turnover (Lee et al. 2012). By providing more accurate earnings forecasts, companies can better meet investors' demand and reduce analysts' workload (Graham et al. 2005). Managers who issue more accurate earnings forecasts build a forecasting reputation, which leads analysts to rely more heavily on them (Williams 1996). Realizing that more accurate forecasting can help them overcome the many disadvantages they face, female CEOs are likely to put additional efforts into, and pay more attention to, their forecasting, which should lead to greater accuracy. Thus, our second hypothesis is as follows:

HYPOTHESIS 2: Female CEOs issue more accurate earnings forecasts than male CEOS.

Our third hypothesis investigates whether female CEOs' efforts in forecasting earnings help them establish their credibility and lead to certain benefits. Specifically, we examine whether female CEOs who provide high-quality earnings forecasts enjoy 
higher analyst following. We focus on analyst following because the number of analysts covering a stock has a significant influence on investors. Prior studies demonstrate that analyst forecasts can improve market efficiency and are closely related to the firm's information environment (Healy and Palepu 2001). Chan and Hameed (2006) find that the stock prices of companies with more analyst coverage incorporate new information faster. Derrien and Kecskés (2013) also find that a decrease in analyst coverage increases information asymmetry and the cost of capital, while the initiation of coverage is viewed positively by investors (Irvine 2003). Conclusively, analyst coverage has a significant effect on the company and its information environment. We therefore stipulate that when female CEOs provide more accurate earnings forecasts, this will convey a clear signal to analysts about their capabilities, which will lead to an increase in analyst following. Our third hypothesis is as follows:

HYPOTHESIS 3: Female CEOs who provide more accurate earnings forecasts enjoy greater analyst following.

\section{Research design, sample selection, and sample description}

\subsection{Research design}

To test our first hypothesis - that female CEOs are more likely than male CEOs to issue earnings forecasts - we use the following Linear probability model (LPM) $\operatorname{model}^{10}$ :

$$
\begin{aligned}
\operatorname{Pr}(M F=1)= & \beta_{0}+\beta_{1} F C E O+\beta_{2} R O A+\beta_{3} L O S S+\beta_{4} N E G C H G+\beta_{5} \text { Volatility } \\
& +\beta_{6} \text { Distress }+\beta_{7} M B+\beta_{8} \text { Follow }+\beta_{9} S I Z E+\beta_{10} \text { Big } \\
& +\beta_{11} I N S T \_O W N+\text { FIRM FE }+ \text { YEAR FE }+\varepsilon
\end{aligned}
$$

The dependent variable in (1) is the likelihood of issuing a management forecast, $M F$, which is equal to 1 when a company provides an annual earnings forecast, and to 0 when it does not. The independent variable of interest is FCEO, which is set to 1 when the CEO is female and to 0 when the CEO is male. According to the first hypothesis, female CEOs have a higher tendency to issue earnings forecasts. Accordingly, we expect the coefficient of $F C E O$ to be positive.

We include an array of control variables that may affect firms' voluntary disclosure decisions. We control for firm profitability using ROA, the return on assets, and LOSS, a binary variable equal to 1 if current earnings are negative, and to 0 otherwise. We control the latter variable, given that firms reporting negative earnings are more likely to stop providing earnings forecasts (e.g., Ajinkya et al. 2005; Graham et al. 2005). However, in order to forestall litigation, firms with a negative earnings change are more likely to disclose this information (Skinner 1994). Thus, we include $N E G C H G$, which

\footnotetext{
${ }^{10}$ It is common to use a linear probability model with a binomial dependent variable when many fixed effects are included in the model. See, for example, Adams and Ferriera (2009), Hanlon and Hoopes (2014), Guo and Masulis (2015), and Fos et al. (2017). The use of a linear probability model does not impose potential bias or inconsistency on the coefficients and standard errors (Greene 2004). Logit models, on the other hand, can result in a significant loss of observations and are less interpretable. We obtain similar results using a logit regression.
} 
is set to 1 if current earnings are smaller than previous year earnings, and to 0 otherwise. Firms with higher earnings volatility are less likely to provide forecasts (Waymire 1985) due to the greater difficulty in predicting earnings under high operational uncertainty. We therefore include VOLATILITY, the monthly stock return volatility over the past 12 months. Lang and Lundholm (1996) find greater analyst following for companies that provide more earnings guidance. We therefore include the variable FOLLOW, the number of analysts following the stock. ${ }^{11}$ Companies audited by Big N firms tend to have better disclosures (Lang and Lundholm 1993). Thus, we use the indicator variable $B I G$ as a proxy for disclosure quality. We also control for the following firm-level characteristics: financial distress, DISTRESS, measured using Zmijewski's Z-Score; the ratio of the market-to-book value, $M B$; and firm size, SIZE, defined as the natural logarithm of total assets. Lastly, we add to the model INST_OWN, the percentage of shares held by institutional investors (e.g., Ajinkya et al. 2005; Baik et al. 2011). A list of all variable definitions is provided in the Appendix. All continuous variables are winsorized at the 1 st and 99 th percentiles to minimize the effect of extreme values. We also include (here and in all other models) firm fixed effects to account for potential missing time-invariant firm characteristics, and year fixed effects to account for systematic variations in the dependent variables across years. We cluster standard errors at the firm and year levels. ${ }^{12}$

Our second hypothesis is that the earnings forecasts of female CEOs are more accurate than those of male CEOs. To test this hypothesis, we run the following OLS model using a sample of companies that issued management forecasts:

$$
\begin{aligned}
\text { MFE }= & \beta_{0}+\beta_{1} \text { FCEO }+\beta_{2} \text { ROA }+\beta_{3} \text { ABILITY }+\beta_{4} L O S S+\beta_{5} A B S C H G+\beta_{6} \text { Volatility } \\
& +\beta_{7} \text { Distress }+\beta_{8} M B+\beta_{9} \text { Follow }+\beta_{10} S I Z E+\beta_{11} \text { Big }+\beta_{12} \text { gap_MF } \\
& +\beta_{13} \text { ABSAEM }+\beta_{14} \text { ABSREM }+\beta_{15} I N S T \_O W N+\text { FIRM FE }+ \text { YEAR FE }+\varepsilon
\end{aligned}
$$

The dependent variable $M F E$, management forecast error, is defined as the absolute difference between management-forecasted earnings per share and actual earnings per share, divided by the stock price and multiplied by 100 . All forecasts included in the sample are either of a specific point or range, in which case we take the midpoint. Considering that earnings forecasts are estimated on a "continued operations" basis and that managers and investors rely more on street earnings than on GAAP earnings (Bradshaw and Sloan 2002), ${ }^{13}$ we use the street earnings reported by IBES to calculate the forecast errors. Because we expect female CEOs to provide more accurate earnings forecasts than male CEOs, their earnings forecast errors should be smaller, and we expect the coefficient of $F C E O$ to be negative.

Baik et al. (2011) find that high-ability CEOs are likely to provide more accurate management forecasts; thus, we control for managerial ability (ABILITY) using two

\footnotetext{
${ }^{11}$ We consider companies not covered by IBES Academic as having no analyst coverage. All results we report in the paper remain unchanged if we use the natural logarithm of the number of analysts, or if we remove the observations with zero analyst coverage in IBES Academic (approximately $0.5 \%$ of the sample).

12 Our results are similar if we cluster only at the firm level.

13 Street earnings are a non-GAAP measure of firms' actual earnings, excluding nonrecurring items such as extraordinary items, earnings from discontinued operations, and other non-operating items. Street earnings are reported by analyst tracking services (e.g., IBES, First Call).
} 
different proxies: 1) ADJROA, the average rank of the industry-adjusted ROA in the previous three years (Rajgopal et al. 2006; Baik et al. 2011), ${ }^{14}$ and 2) DEASCORE, an efficiency score measure based on the data envelope analysis method (Baik et al. 2011; Demerjian et al. 2012). Prior research has shown that larger earnings changes are associated with lower forecast accuracy (Lang and Lundholm 1996). We therefore control for the absolute difference between the current and previous annual earnings per share, $A B S C H G$. Following prior literature on earnings forecasts (e.g., Behn et al. 2008; Gul et al. 2013), we control for the number of days between the issuance of the last management forecast and the end of the fiscal year, GAP $M F$, which has been found to have a negative relationship with forecast accuracy. Finally, previous studies show that managers may use accounting flexibility to meet their forecasts (Kim 2016). Female CEOs are less likely to manage earnings (e.g., Gull et al. 2017; Na and Hong 2017), which may affect earnings forecast accuracy. Thus, we add, to the model, the absolute discretionary accruals, $A B S A E M$, and the absolute abnormal cash flow from operations, $A B S R E M$, calculated using the models of Kothari et al. (2005) and Roychowdhury (2006), respectively. All other variables are defined in Model (1).

Our third hypothesis is that greater efforts in providing earnings forecasts will reward female CEOs in terms of increased analyst following. We first examine whether companies led by female CEOs have more or less analyst coverage. For this, we run the following OLS model:

$$
\begin{aligned}
\text { LEAD_Follow }= & \beta_{0}+\beta_{1} F C E O+\beta_{2} \text { Trade_Vol }+\beta_{3} R O A+\beta_{4} L O S S+\beta_{5} A B S C H G \\
& +\beta_{6} \text { Volatility }+\beta_{7} \text { Distress }+\beta_{8} M B+\beta_{9} S I Z E+\beta_{10} \text { Big } \\
& +\beta_{11} I N S T \_O W N+\beta_{12} \text { FOLLOW }+ \text { FIRM FE }+ \text { YEAR FE }+\varepsilon
\end{aligned}
$$

The dependent variable in Model (3) is LEAD_FOLLOW, the number of analysts following the company in the following year. We use analyst following in the subsequent year because it might take some time for the quality of the manager's forecasts to affect the analysts' stock coverage decision. Our variable of interest is FCEO. A negative coefficient of $F C E O$ will indicate analyst preference toward companies with male CEOs. Alford and Berger (1999) find that stocks that generate more trading volume and thus lead to higher brokerage commissions have increased analyst following. Thus, we control for the annual trading volume, TRADE_VOL. In the model, we also include $F O L L O W$, the number of analysts following the company in the current year due to the stickiness of analyst coverage. All the other variables are defined above.

To examine whether female CEOs are rewarded with more analyst coverage for providing more accurate forecasts, we use the following OLS models:

$$
\begin{aligned}
\text { LEAD_Follow }= & \beta_{0}+\beta_{1} F C E O+\beta_{2} M F+\beta_{3} F C E O \times M F+\beta_{4} \text { Trade_Vol }+\beta_{5} R O A \\
& +\beta_{6} \text { LOSS }+\beta_{7} \text { ABSCHG }+\beta_{8} \text { Volatility }+\beta_{9} \text { Distress }+\beta_{10} M B+\beta_{11} S I Z E \\
& +\beta_{12} \text { Big }+\beta_{13} I N S T \_O W N+\beta_{14} \text { FOLLOW }+ \text { FIRM FE }+ \text { YEAR FE }+\varepsilon
\end{aligned}
$$

\footnotetext{
${ }^{14}$ If the specific CEO has been on the job for less than three years, we use the average ROA for the period she has been on the job. In this specification, we drop $R O A$ from the model due to its high correlation with ADJROA.
} 


$$
\begin{aligned}
\text { LEAD_Follow }= & \beta_{0}+\beta_{1} F C E O+\beta_{2} L O W \_M F E+\beta_{3} H I G H \_M F E+\beta_{4} F C E O \\
& \times L O W \_M F E+\beta_{5} F C E O \times H I G H \_M F E+\beta_{7} \text { Trade_Vol } \\
& +\beta_{8} R O A \beta_{9} L O S S+\beta_{10} A B S C H G+\beta_{11} \text { Volatility }+\beta_{12} \text { Distress } \\
& +\beta_{13} M B+\beta_{14} S I Z E+\beta_{15} \text { Big }+\beta_{16} I N S T \_O W N+\beta_{17} F O L L O W \\
& +F I R M F E+\text { YEAR FE }+\varepsilon
\end{aligned}
$$

In Model (4), we test whether the mere provision of a forecast by a female CEO will lead to higher analyst coverage. Our variable of interest is the interaction variable, $M F x$ FCEO. A positive coefficient will indicate that female CEOs' provision of earnings forecasts leads to a higher increase in analyst following, relative to that of male CEOs. In Model (5), we test whether the provision of more accurate earnings forecasts will benefit female CEOs in terms of greater analyst following. We add, to the model, $L O W \_M F E$, an indicator variable equal to 1 if a company provides earnings forecasts $(M F=1)$ and the management forecast error $(M F E)$ is below the sample median, and to 0 otherwise. Similarly, we add $H I G H \_M F E$, an indicator variable equal to 1 if $M F$ is equal to 1 and $M F E$ is above the sample median, and to 0 otherwise. We then interact each of the variables with $F C E O$. If female CEOs' higher propensity to issue earnings forecasts of greater accuracy affects analyst coverage, we expect positive coefficients of FCEO $x$ LOW MFE.

\subsection{Sample selection and description}

Our sample covers the period from 2000 to 2018. We start in 2000 because very few firms were headed by female CEOs before 2000. In addition, Regulation Fair Disclosure (Reg FD), a major regulatory change with respect to the communication between management and analysts, was passed in 2000. Gender identification mainly comes from Execucomp and is complemented by data from BoardEx, which also provides information on executive gender. ${ }^{15,16}$ If there is more than one CEO during a fiscal year, we manually select the person who is the CEO for most of that fiscal year. We obtain data on management earnings forecasts from IBES Guidance, and on analyst forecasts and street earnings from IBES Academic. Fundamental financial information is obtained from Compustat; stock return-related data are from CRSP; and institutional ownership data are from Thomson Reuters Institutional Holdings. Observations missing the necessary data for the control variables are removed from the sample. After those steps, we have 49,595 firm-year observations to test H1. ${ }^{17}$

Testing H2 involves earnings forecast accuracy; thus, we only consider companies that provide management forecasts. To exclude preliminary earnings announcements,

\footnotetext{
${ }^{15}$ For companies whose International Security Identification Number (ISIN) is given in BoardEx, we use that number to match the CUSIP in Execucomp. For those without an ISIN, we use fuzzy matching with Compustat, based on the similarity of the company names provided. All matches suggested by the software were manually checked and confirmed.

${ }^{16}$ If the gender information from the two sources is inconsistent, we further search the companies' websites and other websites (e.g., Google.com, Bloomberg.com) to confirm the CEO's gender.

${ }^{17}$ As Table 1 shows, some singleton observations are dropped from the models because we include firm and year fixed effects.
} 
we require that management forecasts be released before the end of the fiscal year. Following prior studies (e.g., Waymire 1985; Hirst et al. 1999), we also exclude openended forecasts. ${ }^{18}$ After those additional steps, our sample for testing H2 comprises 13,888 observations.

To test $\mathrm{H} 3$ regarding the consequences of providing management forecasts, we exclude, from our initial sample, observations without the necessary analyst information for the following year. The sample for testing H3 comprises 46,314 observations. Table 1 summarizes the sample formation and composition process.

Panel A of Table 2 presents the sample distribution across the sample period. The percentage of female CEOs increases from $1.54 \%$ in 2000 to $5.02 \%$ in 2018, which is similar to the time trend reported in other gender analyses (e.g., Catalyst 2019). The number of female CEO observations is 1568 , which represents $3.16 \%$ of the total sample. Panel B of Table 2 presents the sample distribution by Fama-French's 12 industries. Female CEOs are relatively overrepresented in the Consumer Nondurables, Transmission, Utilities, Wholesale, and Healthcare industries, and are underrepresented mainly in the Consumer Durables, Energy, Business Equipment, and Manufacturing industries.

Panel C of Table 2 presents a univariate comparison of all variables in our main tests between female and male CEOs. The average $M F$ is 0.353 for companies with female CEOs, which is significantly higher than 0.307 , the average for companies with male CEOs. Thus, female CEOs are $15.0 \%$ more likely than male CEOs to issue earnings forecasts. These results provide preliminary evidence that female CEOs are associated with a higher tendency to issue earnings forecasts. $M F E$ is higher for male CEOs than for female CEOs, but the difference between the two groups is not statistically significant. Thus, the univariate comparison does not show any difference in the management forecast accuracy between the two genders. We also observe significant differences in many firm characteristics between the two groups. In general, female CEOs are hired by less distressed companies and companies with higher profitability and higher growth prospects, as well as companies that are more likely to appoint a Big 4 audit firm. This finding supports the Knippen et al. (2018) conclusion that companies with strong financial health are more likely to appoint a female CEO. Institutional ownership is higher for companies with male CEOs. The average GAP_MF of female CEOs is $11(0.03 \times 365)$ days shorter than that of male CEOs, which means that the last earnings forecast issued by a female CEO is closer to the end of the fiscal year than that issued by a male CEO. Lastly, the comparison of earnings management reveals that female CEOs are less likely to engage in accrual-based earnings management and more likely to engage in real earnings management than male CEOs.

Table 3 provides Pearson correlations for the variables in the smaller sample used to test $\mathrm{H} 2$ and $\mathrm{H} 3$. The correlation tests are generally consistent with the univariate results. The correlations between the independent variables are relatively small. Nonetheless, we check the variance inflation factor (VIF) of each variable tested in each model, and none exceeds 3.5. The relatively low coefficients in the correlation matrix and the VIF results suggest that multicollinearity should not be a concern in this study.

$\overline{{ }^{18} \text { We obtain similar results if we }}$ do not exclude those observations. 
Table 1 Sample construction

\begin{tabular}{lc}
\hline & N \\
\hline Firm-year observations with CEO gender information & 98,910 \\
Less: Missing fundamental information from Compustat & $-36,024$ \\
Less: Missing fundamental information from CRSP & $-12,775$ \\
Less: Singleton observations in the fixed-effect model & -516 \\
Number of observations for testing H1 & 49,595 \\
Less: Observations without a management forecast & $-34,302$ \\
Less: Observations with an open-ended management forecast & -620 \\
Less: Missing information from IBES Analytics & -310 \\
Less: Singleton observations in the fixed-effect model & -475 \\
Number of observations for testing H2 & 13,888 \\
Number of observations for testing H1 & 49,595 \\
Less: Missing analyst forecast data for the following year & -3033 \\
Less: Singleton observations in the fixed-effect model & -248 \\
Number of observations for testing H3 & 46,314 \\
\hline
\end{tabular}

This table describes our sample selection process for the tests of Hypotheses 1, 2, and 3

\section{Empirical results}

Table 4 reports the LPM regression results on the association between CEO gender and the likelihood of management forecast provision (H1). We see that the coefficient of FCEO is positive and statistically significant $(0.046$, t-value $=3.667)$. In economic terms, the relative likelihood of providing an earnings forecast is $15.3 \%$ higher for female CEOs. These results support our first hypothesis. With respect to the control variables, LOSS is negatively associated with $M F$, which is consistent with the argument that companies with negative earnings are more likely to discontinue the provision of earnings forecasts. $N E G C H G$ is positively associated with $M F$, consistent with the observation that companies having bad news choose to disclose that information quickly. VOLATILITY has a negative and significant coefficient, consistent with the idea that it is more challenging to predict earnings under high uncertainty. The coefficient of $M B$ is positive and significant, suggesting that companies with highgrowth prospects are more likely to provide earnings forecasts. The coefficients of FOLLOW, SIZE, BIG, and INST_OWN are all positive and significant, suggesting that companies with more analyst coverage, larger companies, companies audited by Big 4 firms, and companies with higher institutional ownership are more likely to provide earnings forecasts. The remaining variables are insignificant.

Table 5 reports the OLS regression results on the association between female CEOs and management forecast accuracy. We control for the manager's ability using $A D J R O A$, the average of the ranked industry-adjusted ROA in the previous 3 years in Column 1, and DEASCORE, the efficiency score measure based on the data envelope analysis method in Column 2. The results in both columns show that the coefficient of $F C E O$ is negative and significant, which suggests that, after controlling 
Table 2 Sample distribution and descriptive statistics

\begin{tabular}{|c|c|c|c|c|c|c|}
\hline \multicolumn{7}{|c|}{ Panel A: CEO Gender Distribution by Year } \\
\hline & \multicolumn{2}{|l|}{ Male } & \multicolumn{2}{|l|}{ Female } & \multicolumn{2}{|l|}{ Total } \\
\hline & Number & Percent & Number & Percent & Number & Percent \\
\hline 2000 & 2501 & $98.46 \%$ & 39 & $1.54 \%$ & 2540 & $5.12 \%$ \\
\hline 2001 & 2718 & $98.12 \%$ & 52 & $1.88 \%$ & 2770 & $5.59 \%$ \\
\hline 2002 & 2742 & $97.96 \%$ & 57 & $2.04 \%$ & 2799 & $5.64 \%$ \\
\hline 2003 & 2781 & $97.82 \%$ & 62 & $2.18 \%$ & 2843 & $5.73 \%$ \\
\hline 2004 & 2809 & $97.67 \%$ & 67 & $2.33 \%$ & 2876 & $5.80 \%$ \\
\hline 2005 & 2872 & $97.52 \%$ & 73 & $2.48 \%$ & 2945 & $5.94 \%$ \\
\hline 2006 & 2811 & $97.60 \%$ & 69 & $2.40 \%$ & 2880 & $5.81 \%$ \\
\hline 2007 & 2735 & $97.26 \%$ & 77 & $2.74 \%$ & 2812 & $5.67 \%$ \\
\hline 2008 & 2685 & $97.18 \%$ & 78 & $2.82 \%$ & 2763 & $5.57 \%$ \\
\hline 2009 & 2556 & $96.82 \%$ & 84 & $3.18 \%$ & 2640 & $5.32 \%$ \\
\hline 2010 & 2441 & $96.25 \%$ & 95 & $3.75 \%$ & 2536 & $5.11 \%$ \\
\hline 2011 & 2419 & $96.45 \%$ & 89 & $3.55 \%$ & 2508 & $5.06 \%$ \\
\hline 2012 & 2371 & $96.50 \%$ & 86 & $3.50 \%$ & 2457 & $4.95 \%$ \\
\hline 2013 & 2345 & $96.34 \%$ & 89 & $3.66 \%$ & 2434 & $4.91 \%$ \\
\hline 2014 & 2397 & $95.96 \%$ & 101 & $4.04 \%$ & 2498 & $5.04 \%$ \\
\hline 2015 & 2419 & $95.42 \%$ & 116 & $4.58 \%$ & 2535 & $5.11 \%$ \\
\hline 2016 & 2308 & $95.14 \%$ & 118 & $4.86 \%$ & 2426 & $4.89 \%$ \\
\hline 2017 & 2242 & $95.04 \%$ & 117 & $4.96 \%$ & 2359 & $4.76 \%$ \\
\hline 2018 & 1875 & $94.98 \%$ & 99 & $5.02 \%$ & 1974 & $3.98 \%$ \\
\hline Total & 48,027 & $96.84 \%$ & 1568 & $3.16 \%$ & 49,595 & $100.00 \%$ \\
\hline
\end{tabular}

Panel B: CEO Gender Distribution by Industry

\begin{tabular}{lllllll} 
& Male & \multicolumn{3}{c}{ Female } & Total \\
& $\mathrm{N}$ & Percent & $\mathrm{N}$ & Percent & $\mathrm{N}$ & Percent \\
& 2727 & $95.48 \%$ & 129 & $4.52 \%$ & 2856 & $5.76 \%$ \\
$\begin{array}{l}\text { 1 Consumer } \\
\quad \text { Nondurables }\end{array}$ & & & & & & \\
2 Consumer Durables & 1321 & $98.00 \%$ & 27 & $2.00 \%$ & 1348 & $2.72 \%$ \\
3 Manufacturing & 5674 & $97.34 \%$ & 155 & $2.66 \%$ & 5829 & $11.75 \%$ \\
4 Energy & 2518 & $99.57 \%$ & 11 & $0.43 \%$ & 2529 & $5.10 \%$ \\
5 Chemistry & 1451 & $96.93 \%$ & 46 & $3.07 \%$ & 1497 & $3.02 \%$ \\
6 Business Equipment & 11,025 & $97.76 \%$ & 253 & $2.24 \%$ & 11,278 & $22.74 \%$ \\
7 Transmission & 1391 & $94.50 \%$ & 81 & $5.50 \%$ & 1472 & $2.97 \%$ \\
8 Utilities & 1753 & $95.32 \%$ & 86 & $4.68 \%$ & 1839 & $3.71 \%$ \\
9 Wholesale, Retail & 5315 & $95.05 \%$ & 277 & $4.95 \%$ & 5592 & $11.28 \%$ \\
10 Healthcare & 6923 & $96.02 \%$ & 287 & $3.98 \%$ & 7210 & $14.54 \%$ \\
11 Finance & 1711 & $97.27 \%$ & 48 & $2.73 \%$ & 1759 & $3.55 \%$ \\
12 Others & 6218 & $97.37 \%$ & 168 & $2.63 \%$ & 6386 & $12.88 \%$ \\
Total & 48,027 & $96.84 \%$ & 1568 & $3.16 \%$ & 49,595 & $100.00 \%$
\end{tabular}


Table 2 (continued)

\begin{tabular}{|c|c|c|c|c|c|c|c|c|}
\hline \multicolumn{9}{|c|}{ Panel C: Summary Statistics and Univariate Comparisons by CEO Gender } \\
\hline & \multicolumn{3}{|c|}{ Male CEOs } & \multicolumn{3}{|c|}{ Female CEOs } & \multicolumn{2}{|c|}{ Mean difference } \\
\hline & $\mathrm{N}$ & Mean & STD & $\mathrm{N}$ & Mean & STD & Difference & T-statistics \\
\hline $\mathrm{MF}$ & 48,027 & 0.307 & 0.461 & 1568 & 0.353 & 0.478 & $-0.046 * * *$ & -3.862 \\
\hline NEGCHG & 48,027 & 0.431 & 0.495 & 1568 & 0.432 & 0.495 & -0.001 & -0.051 \\
\hline MFE & 13,391 & 0.751 & 2.453 & 497 & 0.686 & 2.136 & 0.065 & 0.581 \\
\hline GAP_MF & 13,391 & 0.238 & 0.191 & 497 & 0.208 & 0.171 & $0.030 * * *$ & 3.473 \\
\hline FOLLOW & 13,391 & 13.073 & 8.171 & 497 & 13.654 & 7.973 & -0.581 & -1.558 \\
\hline $\mathrm{ROA}$ & 13,391 & 0.046 & 0.091 & 497 & 0.055 & 0.086 & $-0.009 * *$ & -2.101 \\
\hline LOSS & 13,391 & 0.131 & 0.338 & 497 & 0.125 & 0.331 & 0.007 & 0.429 \\
\hline VOLATILITY & 13,391 & 0.099 & 0.055 & 497 & 0.098 & 0.056 & 0.002 & 0.639 \\
\hline ABSCHG & 13,391 & 0.052 & 0.145 & 497 & 0.057 & 0.165 & -0.005 & -0.792 \\
\hline DISTRESS & 13,391 & -3.200 & 1.146 & 497 & -3.347 & 1.199 & $0.148^{* * * *}$ & 2.815 \\
\hline MB & 13,391 & 3.469 & 4.623 & 497 & 3.964 & 5.572 & $-0.495 * *$ & -2.325 \\
\hline SIZE & 13,391 & 7.518 & 1.671 & 497 & 7.643 & 1.913 & -0.125 & -1.631 \\
\hline BIG & 13,391 & 0.933 & 0.250 & 497 & 0.962 & 0.192 & $-0.029 * *$ & -2.547 \\
\hline INST_OWN & 13,391 & 0.600 & 0.386 & 497 & 0.514 & 0.432 & $0.086^{* * * *}$ & 4.880 \\
\hline AEM & 13,391 & 0.003 & 0.057 & 497 & -0.006 & 0.058 & $0.009 * * *$ & 3.513 \\
\hline ABSAEM & 13,391 & 0.041 & 0.040 & 497 & 0.042 & 0.040 & -0.001 & -0.684 \\
\hline REM & 13,391 & 0.008 & 0.079 & 497 & 0.019 & 0.070 & $-0.011 * * *$ & -3.102 \\
\hline ABSREM & 13,391 & 0.058 & 0.062 & 497 & 0.053 & 0.060 & $0.005^{*}$ & 1.670 \\
\hline
\end{tabular}

This table presents a comparison between the subsamples of companies with female CEOs and male CEOs. Panel A presents the distribution of subsamples by year, and Panel B presents the distribution by FamaFrench's 12 industries. Panel C provides descriptive statistics and univariate comparisons of the variables used in the analysis between female and male CEOs. Variable definitions are provided in the Appendix. All continuous variables are winsorized at the top and bottom $1 \%$. Significance at the $10 \%, 5 \%$, and $1 \%$ levels is indicated by $*, * *$, and $* * *$, respectively

for other factors that affect forecast accuracy, forecasts issued by female CEOs have smaller errors. In economic terms, relative to the forecast errors of male CEOs, female CEOs' forecast errors are $40.0 \%$ (39.2\%) smaller when we control for CEO ability using ADJROA (DEASCORE).

With regard to the control variables, we first note that our two measures of CEO ability are negatively associated with forecast errors, suggesting that more able managers issue more accurate forecasts. Management forecast errors are larger for firms with high earnings changes, loss firms, distressed firms, and firms with high stock price volatility. The earnings forecasts disclosed by larger firms and more profitable firms are more accurate. The number of analysts following the stock has a significantly negative relationship with forecast errors, suggesting that the forecasts of firms with more analyst coverage are more accurate. This finding is consistent with the evidence in Graham et al. (2005) and Lang and Lundholm (1996). GAP MF is positively associated with management forecast errors, which means that the forecasts issued closer to the end of the fiscal year are more accurate, given that they contain more recent 


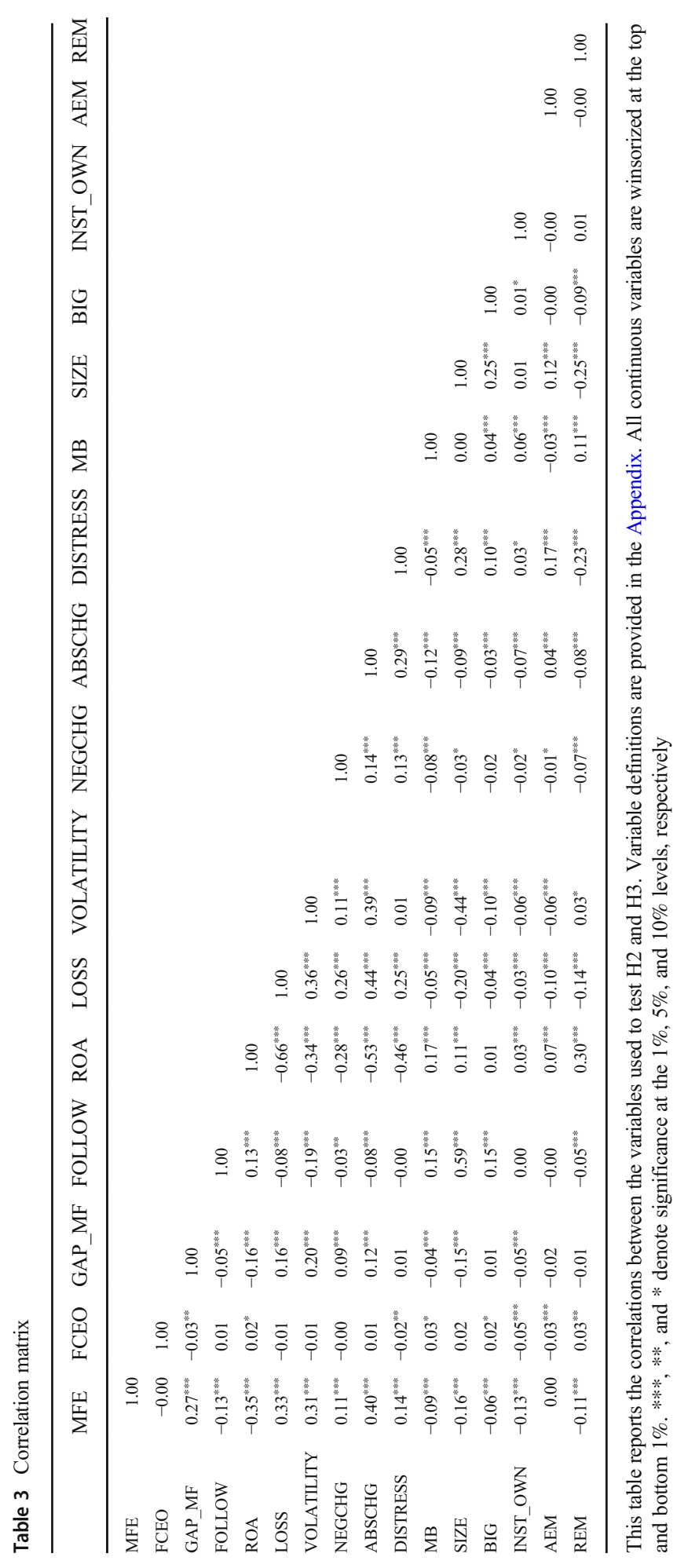


Table 4 Earnings forecast issuance by CEO gender
MF

\begin{tabular}{|c|c|}
\hline & $\mathrm{MF}$ \\
\hline FCEO & $\begin{array}{l}0.046^{* * *} \\
(3.667)\end{array}$ \\
\hline ROA & $\begin{array}{l}-0.004 \\
(-0.288)\end{array}$ \\
\hline LOSS & $\begin{array}{l}-0.060^{\text {**** }} \\
(-12.704)\end{array}$ \\
\hline NEGCHG & $\begin{array}{l}0.013^{* * * *} \\
(4.318)\end{array}$ \\
\hline VOLATILITY & $\begin{array}{l}-0.093^{* * *} \\
(-4.196)\end{array}$ \\
\hline DISTRESS & $\begin{array}{l}-0.002 \\
(-1.066)\end{array}$ \\
\hline MB & $\begin{array}{l}0.001^{* *} \\
(2.081)\end{array}$ \\
\hline FOLLOW & $\begin{array}{l}0.006^{* * *} \\
(10.447)\end{array}$ \\
\hline SIZE & $\begin{array}{l}0.044^{* * *} \\
(11.915)\end{array}$ \\
\hline $\mathrm{BIG}$ & $\begin{array}{l}0.038^{* * * *} \\
(5.749)\end{array}$ \\
\hline INST_OWN & $\begin{array}{l}0.025^{* *} \\
(2.529)\end{array}$ \\
\hline Intercept & $\begin{array}{l}-0.046^{*} \\
(-1.953)\end{array}$ \\
\hline Firm FE & YES \\
\hline Year FE & YES \\
\hline Adj. R-sq. & 0.598 \\
\hline $\mathrm{N}$ & 49,595 \\
\hline
\end{tabular}

This table presents the linear probability model (LPM) regression results of Model (1). The dependent variable is $M F$, an indicator variable equal to 1 if a company provides annual earnings forecasts, and to 0 otherwise. The independent variable of interest is the CEO's gender, $F C E O$. Both firm and year fixed effects are included. Variable definitions are shown in the Appendix. All continuous variables are winsorized at the top and bottom $1 \%$. t-statistics are reported in parentheses, and ${ }^{* * *},{ }^{* *}$, and * denote significance at the $1 \%$, $5 \%$, and $10 \%$ levels, respectively

information. ${ }^{19}$ Finally, institutional ownership is negatively associated with management forecast errors.

The results related to our third hypothesis (on the association between earnings forecasts by female CEOs and analyst following) are in Table 6. Column 1 reports the results of Model (3). The coefficient of FCEO is negative and significant at the 5\% level. This finding suggests that, on average, analysts prefer to follow companies with male CEOs. ${ }^{20}$ Column 2 reports the results of Model (4). We see that the coefficient of

\footnotetext{
${ }^{19}$ Because we report in Table 2, Panel $\mathrm{C}$ that GAP_MF is shorter for female CEOs and is positively correlated with MFE, we repeat this test using the first earnings forecast. The coefficient on FCEO remains negative and significant, suggesting that the more accurate forecasts are not more accurate merely because they provide forecasts at later times. ${ }^{20}$ We consider two possible explanations concerning analysts' preference for companies headed by male CEOs. One is that analysts hold a negative bias against female CEOs and therefore refrain from following their companies. The other is that male CEOs communicate privately with financial analysts more than female CEOs do, which incentivizes analysts to prefer male-led companies.
} 
Table 5 Earnings forecast accuracy by CEO gender

\begin{tabular}{|c|c|c|}
\hline & MFE & MFE \\
\hline FCEO & $\begin{array}{l}-0.304^{* *} \\
(-2.140)\end{array}$ & $\begin{array}{l}-0.298^{* * *} \\
(-2.102)\end{array}$ \\
\hline ROA & & $\begin{array}{l}-1.488^{* *} \\
(-2.209)\end{array}$ \\
\hline ADJROA & $\begin{array}{l}-0.004^{* * *} \\
(-3.239)\end{array}$ & \\
\hline DEASCORE & & $\begin{array}{l}-0.729^{* *} \\
(-2.217)\end{array}$ \\
\hline LOSS & $\begin{array}{l}0.810^{* * * *} \\
(7.739)\end{array}$ & $\begin{array}{l}0.761^{* * * *} \\
(6.797)\end{array}$ \\
\hline ABSCHG & $\begin{array}{l}1.958^{* * * *} \\
(6.931)\end{array}$ & $\begin{array}{l}1.790^{* * * *} \\
(6.018)\end{array}$ \\
\hline VOLATILITY & $\begin{array}{l}4.103^{* * * *} \\
(4.556)\end{array}$ & $\begin{array}{l}4.281^{* * * *} \\
(4.713)\end{array}$ \\
\hline DISTRESS & $\begin{array}{l}0.121^{* * * *} \\
(3.050)\end{array}$ & $\begin{array}{l}0.055^{*} \\
(1.651)\end{array}$ \\
\hline MB & $\begin{array}{l}-0.008^{*} \\
(-1.700)\end{array}$ & $\begin{array}{l}-0.007 \\
(-1.581)\end{array}$ \\
\hline FOLLOW & $\begin{array}{l}-0.016^{* * *} \\
(-3.214)\end{array}$ & $\begin{array}{l}-0.018^{* * *} \\
(-3.626)\end{array}$ \\
\hline SIZE & $\begin{array}{l}-0.117^{* *} \\
(-2.079)\end{array}$ & $\begin{array}{l}-0.102^{*} \\
(-1.908)\end{array}$ \\
\hline BIG & $\begin{array}{l}0.076 \\
(0.393)\end{array}$ & $\begin{array}{l}0.079 \\
(0.410)\end{array}$ \\
\hline GAP_MF & $\begin{array}{l}2.343^{* * *} \\
(15.940)\end{array}$ & $\begin{array}{l}2.342^{* * *} \\
(15.772)\end{array}$ \\
\hline ABSAEM & $\begin{array}{l}0.697 \\
(1.128)\end{array}$ & $\begin{array}{l}0.694 \\
(1.111)\end{array}$ \\
\hline ABSREM & $\begin{array}{l}0.664 \\
(1.295)\end{array}$ & $\begin{array}{l}0.610 \\
(1.178)\end{array}$ \\
\hline INST_OWN & $\begin{array}{l}-0.316^{* *} \\
(-2.193)\end{array}$ & $\begin{array}{l}-0.287^{* * *} \\
(-2.000)\end{array}$ \\
\hline Intercept & $\begin{array}{l}1.318^{* *} \\
(2.533)\end{array}$ & $\begin{array}{l}1.563^{* * * *} \\
(2.763)\end{array}$ \\
\hline Firm FE & YES & YES \\
\hline Year FE & YES & YES \\
\hline Pseudo R-sq. & 0.533 & 0.535 \\
\hline $\mathrm{N}$ & 13,888 & 13,854 \\
\hline
\end{tabular}

This table presents the OLS regression results of Model (2). The dependent variable is the management forecast error, MFE. The independent variable of interest is the CEO's gender, FCEO. In Columns (1) and (2), we control for CEO ability using ADJROA and DEASCORE, respectively. ADJROA is the average ranked industry-adjusted ROA for the previous (up to) three years for the same CEO. DEASCORE is the firm operating efficiency score, estimated using data envelopment analysis. Both firm and year fixed effects are included. Variable definitions are shown in the Appendix. All continuous variables are winsorized at the top and bottom $1 \%$. t-statistics are reported in parentheses, and ${ }^{* * *},{ }^{* *}$, and ${ }^{*}$ denote significance at the $1 \%, 5 \%$, and $10 \%$ levels, respectively 
the interaction term $F C E O$ × $M F$ is insignificant and that the coefficient of FCEO remains negative and significant. This finding suggests that, on average, the mere provision of management forecasts does not alter analysts' preference for male-led companies. Column 3 reports the results of Model (5) and shows that, as expected, the coefficient of $L O W \_M F E$ is positive and significant, whereas the coefficient of HIGH_MFE is insignificant. These results mean that the provision of more accurate management forecasts (smaller forecast errors) is rewarded with more analyst coverage, whereas the provision of less accurate management forecasts is not. More important for our study, the coefficient of FCEO $x$ LOW_MFE is significant at the 5\% level, while the coefficient of FCEO $\times H_{I G H}$ MFE is insignificant. These results suggest that providing more accurate earnings forecasts helps female CEOs to increase their analyst coverage, relative to male CEOs. Moreover, the sum of the coefficients of FCEO and FCEO $\times$ LOW_MFE, reported at the bottom of the table, is insignificant ( $\mathrm{p}$ value = 0.45 ). This finding indicates that the provision of more accurate management forecasts allows female CEOs to eliminate the gap in analyst following relative to companies with male CEOs. The insignificant coefficient of FCEO $x$ HIGH_MFE suggests that the provision of less accurate management forecasts does not help reduce the gap. ${ }^{21}$ Overall, the results suggest that the high efforts of female CEOs to issue accurate earnings forecasts can help reduce the gender gap in analyst following.

\section{Supplementary analysis and robustness checks}

\subsection{Other evidence on female CEOs' effort}

We posit and find that female CEOs make greater efforts to meet the information needs of investors and analysts by providing more accurate management forecasts. We corroborate this finding by providing evidence on 1) the frequency of female CEOs updating their earnings forecasts, and 2) the content of their $10-\mathrm{K}$ disclosures.

We follow Baik et al. (2011) and examine not only the likelihood of issuing earnings forecasts but also whether the frequency of forecast issuance (including updates to the original forecasts) is higher for female CEOs than for male CEOs. A higher frequency of forecast issuance by female CEOs will further demonstrate that they make greater efforts to keep stock market participants informed.

Panel A of Table 7 provides a univariate comparison of the frequency of forecasts between male and female CEOs. Using the full sample (including companies not issuing earnings forecasts), the frequency is 1.437 for male CEOs and 1.776 for female CEOs; the difference is statistically significant. This finding indicates that female CEOs provide $23.6 \%$ more earnings forecasts. Because this test reflects the effects of both providing and revising forecasts, we also report the results for the sample of companies issuing forecasts. On average, male CEOs provide 4.676 disclosures (including revisions), whereas female CEOs provide 4.936 (a relative difference of 5.6\%). Thus, female CEOs are more likely to issue forecasts and make more timely updates to those forecasts. Panel B provides the multivariate results of an OLS regression in which we repeat Model (1) replacing the

\footnotetext{
${ }^{21}$ An alternative research design that only includes observations with management forecasts and uses a single indicator variable for management forecast accuracy $\left(L O W \_M F E\right)$ shows similar results.
} 
Table 6 Analyst following and CEO gender

\begin{tabular}{|c|c|c|c|}
\hline & LEAD_FOLLOW & LEAD_FOLLOW & LEAD_FOLLOW \\
\hline FCEO & $\begin{array}{l}-0.225^{* *} \\
(-2.224)\end{array}$ & $\begin{array}{l}-0.277^{* *} \\
(-2.139)\end{array}$ & $\begin{array}{l}-0.298^{* *} \\
(-2.327)\end{array}$ \\
\hline MF & & $\begin{array}{l}0.048 \\
(1.167)\end{array}$ & \\
\hline $\mathrm{FCEO} \times \mathrm{MF}$ & & $\begin{array}{l}0.112 \\
(0.609)\end{array}$ & \\
\hline LOW_MFE & & & $\begin{array}{l}0.200^{* * * *} \\
(3.787)\end{array}$ \\
\hline HIGH_MFE & & & $\begin{array}{l}-0.064 \\
(-1.379)\end{array}$ \\
\hline FCEO $\times$ LOW_MFE & & & $\begin{array}{l}0.432^{* *} \\
(2.043)\end{array}$ \\
\hline FCEO $\times$ HIGH_MFE & & & $\begin{array}{l}-0.161 \\
(-0.697)\end{array}$ \\
\hline TRADE_VOL & $\begin{array}{l}0.059^{* * * *} \\
(8.265)\end{array}$ & $\begin{array}{l}0.059^{* * *} \\
(8.291)\end{array}$ & $\begin{array}{l}0.060^{* * * *} \\
(8.433)\end{array}$ \\
\hline ROA & $\begin{array}{l}0.206 \\
(1.518)\end{array}$ & $\begin{array}{l}0.207 \\
(1.521)\end{array}$ & $\begin{array}{l}0.209 \\
(1.538)\end{array}$ \\
\hline LOSS & $\begin{array}{l}-0.278^{* * *} \\
(-7.719)\end{array}$ & $\begin{array}{l}-0.275^{\text {**** }} \\
(-7.629)\end{array}$ & $\begin{array}{l}-0.271^{* * * *} \\
(-7.528)\end{array}$ \\
\hline ABSCHG & $\begin{array}{l}-0.714^{* * *} \\
(-15.688)\end{array}$ & $\begin{array}{l}-0.714^{* * *} \\
(-15.691)\end{array}$ & $\begin{array}{l}-0.714^{* * *} \\
(-15.679)\end{array}$ \\
\hline VOLATILITY & $\begin{array}{l}0.224 \\
(1.154)\end{array}$ & $\begin{array}{l}0.228 \\
(1.177)\end{array}$ & $\begin{array}{l}0.238 \\
(1.229)\end{array}$ \\
\hline DISTRESS & $\begin{array}{l}-0.100^{* * * *} \\
(-5.293)\end{array}$ & $\begin{array}{l}-0.100^{* * * *} \\
(-5.282)\end{array}$ & $\begin{array}{l}-0.099^{* * * *} \\
(-5.208)\end{array}$ \\
\hline MB & $\begin{array}{l}0.049^{* * * *} \\
(14.709)\end{array}$ & $\begin{array}{l}0.049^{* * *} \\
(14.701)\end{array}$ & $\begin{array}{l}0.049^{* * * *} \\
(14.663)\end{array}$ \\
\hline FOLLOW & $\begin{array}{l}0.702^{* * *} \\
(115.504)\end{array}$ & $\begin{array}{l}0.702^{* * *} \\
(115.193)\end{array}$ & $\begin{array}{l}0.701^{\text {**** }} \\
(115.191)\end{array}$ \\
\hline SIZE & $\begin{array}{l}0.507^{* * * *} \\
(14.518)\end{array}$ & $\begin{array}{l}0.504^{* * *} \\
(14.459)\end{array}$ & $\begin{array}{l}0.508^{* * *} \\
(14.540)\end{array}$ \\
\hline BIG & $\begin{array}{l}0.051 \\
(1.072)\end{array}$ & $\begin{array}{l}0.048 \\
(1.027)\end{array}$ & $\begin{array}{l}0.049 \\
(1.046)\end{array}$ \\
\hline INST_OWN & $\begin{array}{l}0.250^{* * *} \\
(3.735)\end{array}$ & $\begin{array}{l}0.249^{* * *} \\
(3.721)\end{array}$ & $\begin{array}{l}0.244^{* * * *} \\
(3.665)\end{array}$ \\
\hline Intercept & $\begin{array}{l}-1.001^{* * *} \\
(-4.530)\end{array}$ & $\begin{array}{l}-0.996^{\text {*** }} \\
(-4.508)\end{array}$ & $\begin{array}{l}-1.019^{\text {**** }} \\
(-4.611)\end{array}$ \\
\hline Firm FE & YES & YES & YES \\
\hline Year FE & YES & YES & YES \\
\hline Adj. R-Sq. & 0.942 & 0.942 & 0.942 \\
\hline $\mathrm{N}$ & 46,314 & 46,314 & 46,314 \\
\hline
\end{tabular}


Table 6 (continued)

LEAD_FOLLOW LEAD_FOLLOW LEAD_FOLLOW

F-test:

FCEO + FCEO $x$ LOW_MFE

$(0.452)$

This table presents the OLS regression results of Models (3), (4), and (5) in Columns 1, 2, and 3, respectively. The dependent variable is $L E A D \_F O L L O W$, the number of analysts following the stock in the following year. $M F$ is an indicator variable equal to 1 if a company issues an annual earnings forecast, and to 0 otherwise. $L O W \_M F E$ (HIGH_MFE) is an indicator variable equal to 1 if a company provides an earnings forecast and the earnings forecast error is below (above) the sample median, and to 0 otherwise. Both firm and year fixed effects are included. Variable definitions are shown in the Appendix. All continuous variables are winsorized at the top and bottom $1 \%$. t-statistics are reported in parentheses, and ${ }^{* * *},{ }^{* *}$, and ${ }^{*}$ denote significance at the $1 \%, 5 \%$, and $10 \%$ levels, respectively

dependent variable $M F$ with $F R E Q U E N C Y$, the number of annual management earnings forecasts disclosed in 1 year, including forecast revisions. The results in Column 1 show that female CEOs provide more frequent forecast disclosures, and the relative difference is $18.0 \%$. In Column 2, where we only consider companies that issued management forecasts during the year, the coefficient of $F C E O$ remains positive and significant at the $10 \%$ level. The relative increase in the forecast frequency for female CEOs is $7.5 \%$. This finding implies that female CEOs provide more frequent updates to their forecasts, informing investors more promptly about changes in their expectations of future profitability. In addition, as we already report in Table 2, Panel C, the variable GAP_MF is significantly smaller for female CEOs. This result means that female CEOs continue to update their forecasts later in the year than do male CEOs. In Column 3, we report the multivariate analysis on the relations between GAP_MF and CEO gender. Consistent with the univariate results, the coefficient of FCEO is negative and significant, suggesting that the number of days between the issuance of the last management forecast and the end of the fiscal year is shorter for female CEOs. ${ }^{22}$ Overall, our findings of more forecast updates during the year and of later updates by female CEOs complement each other and paint a complete picture of female CEOs making greater efforts to keep the users of forecasts informed.

We also analyze the content of $10-\mathrm{K}$ reports to provide further evidence on female CEOs' efforts. While the $10-\mathrm{K}$ report is mandatory, managers can exercise some judgment over its content. We examine three aspects of the report: its length, use of graphics, and use of unique words. We complement this analysis by examining the Gunning Fog index (Gunning 1952), the SMOG Fog index (McLaughlin 1969), and the average length of the sentences.

We use the natural logarithm of the file size, FILESIZE (Loughran and McDonald 2014), and the natural logarithm of the number of words, WORD (Li 2008), to measure the length of $10-\mathrm{K}$ reports. The univariate results in Panel A of Table 8 and the multivariate results in the first two columns of Panel B show that the $10-\mathrm{K}$ reports of female CEOs contain more words and have a larger file size than those of male CEOs. This finding may suggest that female CEOs provide more valuable information to

\footnotetext{
${ }^{22}$ In untabulated results, we further find weakly significant evidence that the timespan from the first earnings forecast to the last forecast update is longer for female CEOs.
} 
Table 7 Earnings forecast frequency and forecast horizon

\begin{tabular}{|c|c|c|c|c|c|c|c|c|}
\hline \multicolumn{9}{|c|}{ Panel A: Summary Statistics and Univariate Comparisons by CEO Gender } \\
\hline & \multicolumn{3}{|l|}{ Male CEOs } & \multicolumn{3}{|c|}{ Female CEOs } & \multicolumn{2}{|c|}{ Mean Difference } \\
\hline & $\mathrm{N}$ & Mean & STD & $\mathrm{N}$ & Mean & STD & Difference & T-statistics \\
\hline Frequency (H1 sample) & 48,027 & 1.437 & 2.579 & 1568 & 1.776 & 3.014 & $-0.338 * * *$ & -5.081 \\
\hline Frequency (H2 sample) & 13,391 & 4.676 & 2.618 & 497 & 4.936 & 3.162 & $-0.260 * *$ & -2.158 \\
\hline \multicolumn{9}{|c|}{ Panel B: Multivariate Regression - Earnings Forecast Frequency } \\
\hline & Frequency & Frequency & GAP_MF & & & & & \\
\hline & H1 Sample & H2 Sample & & & & & & \\
\hline \multirow[t]{2}{*}{ FCEO } & $0.259^{* * * *}$ & $0.352^{*}$ & $-0.023^{* * *}$ & & & & & \\
\hline & (2.992) & (1.871) & $(-2.296)$ & & & & & \\
\hline \multirow[t]{2}{*}{ ROA } & $-0.148^{* *}$ & $1.014^{* * * *}$ & $-0.174^{* * *}$ & & & & & \\
\hline & $(-2.063)$ & (3.314) & $(-5.164)$ & & & & & \\
\hline \multirow[t]{2}{*}{ LOSS } & $-0.331^{* * * *}$ & $-0.291^{* * * *}$ & $0.051^{* * * * *}$ & & & & & \\
\hline & $(-14.029)$ & $(-3.643)$ & $(6.751)$ & & & & & \\
\hline \multirow[t]{2}{*}{ NEGCHG } & $0.041^{* *}$ & 0.048 & $0.011^{* * * *}$ & & & & & \\
\hline & $(2.467)$ & (1.155) & (3.625) & & & & & \\
\hline \multirow[t]{2}{*}{ VOLATILITY } & $-0.326^{* * * *}$ & -0.026 & $0.115^{* *}$ & & & & & \\
\hline & $(-3.211)$ & $(-0.059)$ & $(2.357)$ & & & & & \\
\hline \multirow[t]{2}{*}{ DISTRESS } & -0.017 & 0.006 & -0.004 & & & & & \\
\hline & $(-1.568)$ & $(0.174)$ & $(-1.292)$ & & & & & \\
\hline \multirow[t]{2}{*}{ MB } & $0.004^{* *}$ & 0.003 & -0.000 & & & & & \\
\hline & $(2.182)$ & $(0.580)$ & $(-0.674)$ & & & & & \\
\hline \multirow[t]{2}{*}{ FOLLOW } & $0.027^{* * * *}$ & $0.021^{* * * *}$ & 0.001 & & & & & \\
\hline & $(9.041)$ & (3.209) & (1.059) & & & & & \\
\hline \multirow[t]{2}{*}{ SIZE } & $0.307^{* * * *}$ & $0.513^{* * * *}$ & -0.005 & & & & & \\
\hline & (14.999) & (7.992) & $(-0.993)$ & & & & & \\
\hline \multirow[t]{2}{*}{ BIG } & $0.303^{* * *}$ & 0.133 & 0.011 & & & & & \\
\hline & (10.112) & $(1.001)$ & $(0.748)$ & & & & & \\
\hline \multirow[t]{2}{*}{ INST_OWN } & $0.111^{* *}$ & 0.113 & -0.013 & & & & & \\
\hline & $(2.063)$ & $(0.963)$ & $(-1.276)$ & & & & & \\
\hline \multirow[t]{2}{*}{ Intercept } & $-0.982^{* * *}$ & 0.336 & $0.239^{* * * *}$ & & & & & \\
\hline & $(-7.707)$ & $(0.652)$ & $(5.679)$ & & & & & \\
\hline Firm FE & YES & YES & YES & & & & & \\
\hline Year FE & YES & YES & YES & & & & & \\
\hline Adj. R-sq. & 0.614 & 0.410 & 0.310 & & & & & \\
\hline $\mathrm{N}$ & 49,595 & 13,888 & 13,888 & & & & & \\
\hline
\end{tabular}

This table presents the OLS regression results of Model (1), where the dependent variable $M F$ is replaced with Frequency, the number of forecasts provided, which includes revisions to the forecast. Panel A reports a univariate comparison of the values of Frequency between male and female CEOs for the larger sample used to test $\mathrm{H} 1$ and the smaller sample used to test $\mathrm{H} 2$. Panel B reports the multivariate results. Column 3 reports multivariate results on the relations between $G A P_{-} M F$, the number of calendar days from the issuance of the management forecast to the end of the fiscal year, divided by 365 (days). Both firm and year fixed effects are included. Variable definitions are shown in the Appendix. All continuous variables are winsorized at the top and bottom $1 \%$. t-statistics are reported in parentheses, and ${ }^{* * *},{ }^{* *}$, and ${ }^{*}$ denote significance at the $1 \%, 5 \%$, and $10 \%$ levels, respectively 
financial information users. However, Li (2008) and Loughran and McDonald (2014) argue that longer reports may indicate lower readability, as they take longer to read and process. As a result, the length of the report can be used strategically to make the report less transparent and to conceal unfavorable information by overflowing the report with irrelevant information. We therefore examine other aspects of the report.

We examine the use of exhibits in the $10-\mathrm{K}$ because the SEC recognizes the potential benefits of graphics in communicating financial information to users in a manner that is easier to read and understand (SEC 1998). ${ }^{23}$ Moreover, Loughran and McDonald (2016) assert that non-textual materials enhance the reader's ability to understand the information. Consistent with the ability of data visualization to facilitate the effective communication of relevant valuation information to $10-\mathrm{K}$ users, Christensen et al. (2021) find significantly positive associations between infographics and the magnitude of both 10-K filing abnormal returns and analysts' forecast revisions. The results in Column 3 of Panel C show that female CEOs make greater use of infographics, suggesting that they are more attentive to the needs of information users. We also examine the use of unique words using the variable UNIQUE, the natural logarithm of the number of unique words in the 10-K report. If the intent is to mislead investors, we would expect to see more repetition in the reports. However, as shown in Panel A and in Column 4 of Panel B, female CEOs use more unique words. This again suggests that female CEOs provide more information in 10-K filings than male CEOs.

We complement this analysis by calculating the Fog index (either the Gunning Fog index or the SMOG Fog index) and the average sentence length, AVE_LENGTH (which is one of the two components of the Gunning Fog index). The univariate results in Panel A show higher values for female CEOs. However, as Lougharn and McDonald (2016) show, differences in the Fog index between groups can be statistically significant without having a meaningful difference. This seems to be the case here, as the univariate results suggest a difference of only 0.2 years in education in terms of readability. Even more importantly, after controlling for firm characteristics, the multivariate results reported in Panel C of Table 4 show no statistical difference between the two genders on all measures. Considering all evidence together, we conclude that female CEOs provide more useful information to $10-\mathrm{K}$ users without making $10-\mathrm{K}$ reports more complex.

\subsection{Earnings forecast errors and analyst forecast errors}

Research has shown that forecast accuracy has a significant effect on financial analysts' careers. For example, Mikhail et al. (1999) find that analysts who issue less accurate forecasts are more likely to be replaced. According to Hong and Kubik (2003), analysts who are more accurate forecasters are more likely to move up to a high-status brokerage house. Consistent with analysts wanting to forecast accurately, Williams (1996) shows that they tend to rely more on the forecasts of managers who have established a reputation for accuracy. These arguments suggest that financial analysts will rely more on the earnings forecasts of female CEOs than those of male CEOs if they believe the female CEOs' forecasts are more accurate. On the other hand, similar to investors, analysts may

\footnotetext{
${ }^{23}$ To facilitate the use of graphics in regulatory filings, in 2000 the SEC updated its Electronic Data Gathering, Analysis, and Retrieval (EDGAR) system to allow HTML files containing embedded tags for graphic or image files (SEC 2000).
} 


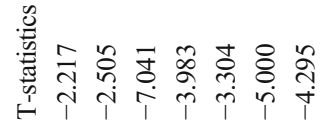

$\underset{0}{0}$

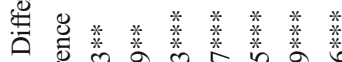

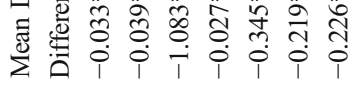

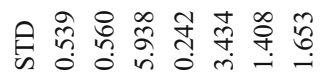

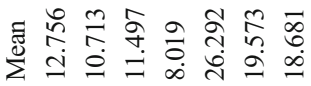

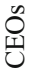

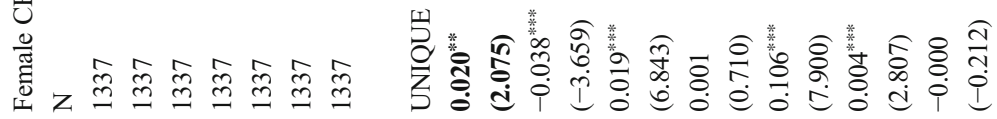

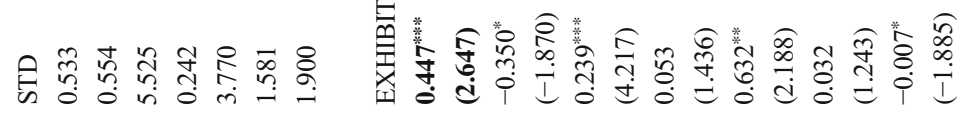

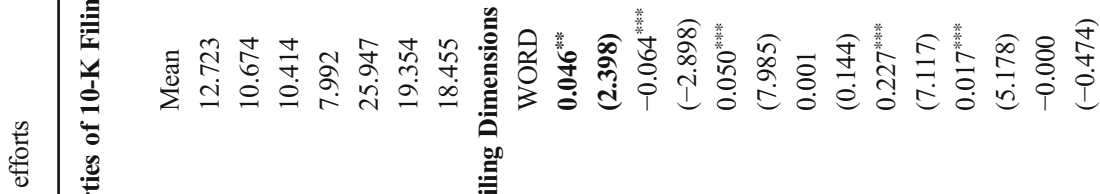




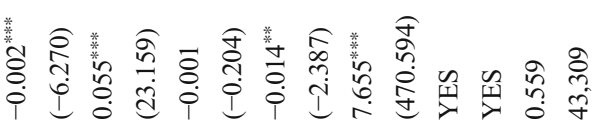

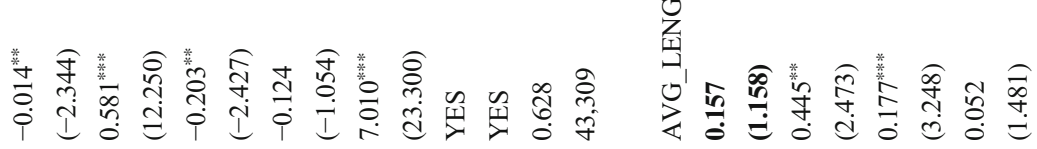

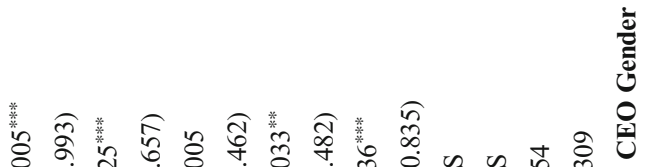

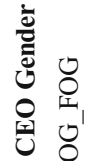

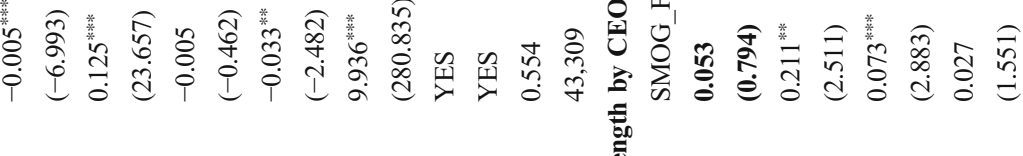

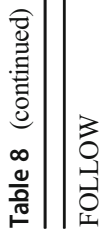

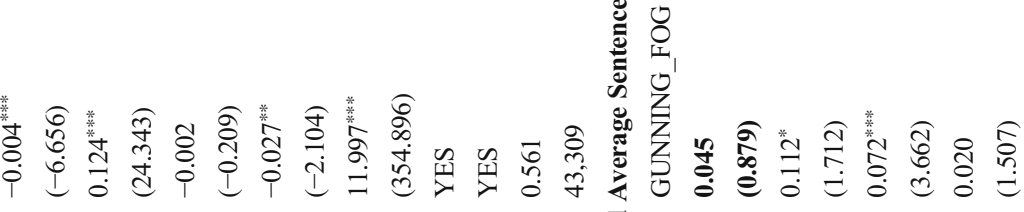

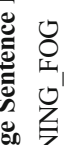
롫

롤

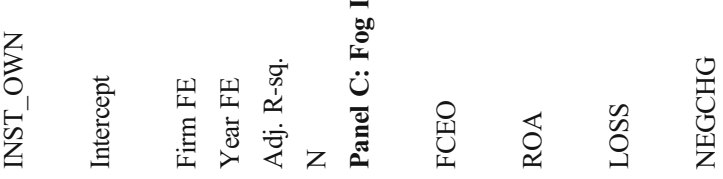




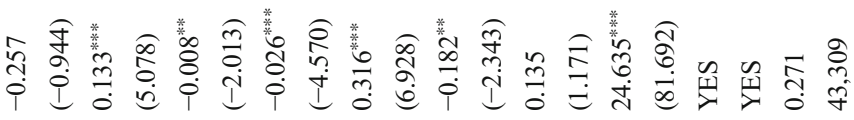

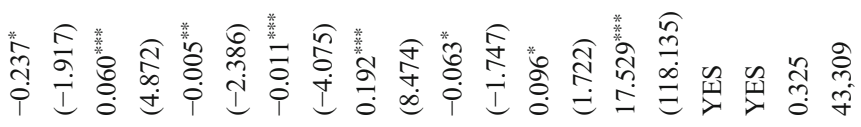

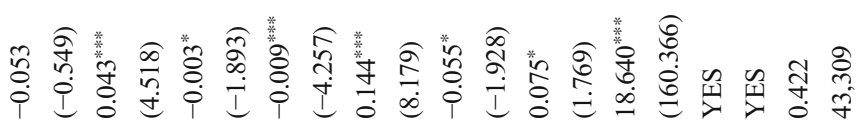

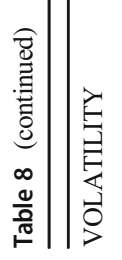

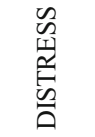

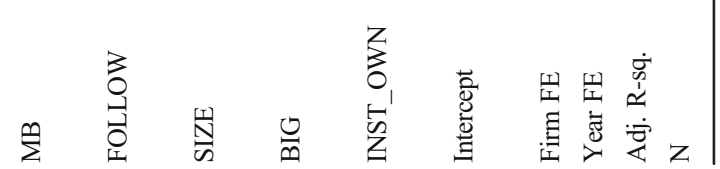

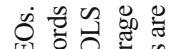

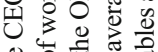

일

क्षे है

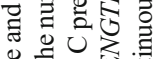

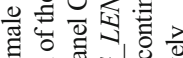

司

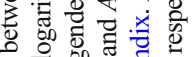

象

证

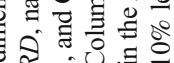

के

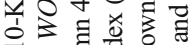

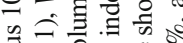

死 000 o

在

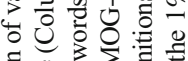

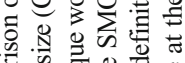

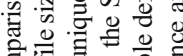

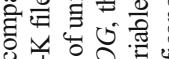

它 0

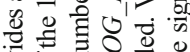

항 훌

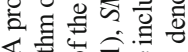

《赔额.

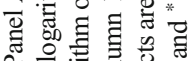

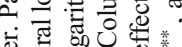

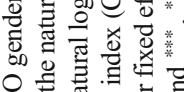

을 음

낭

흔

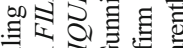

进

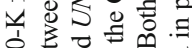

o o

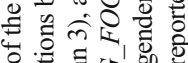

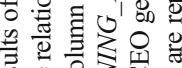

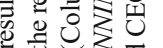

计

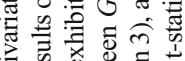

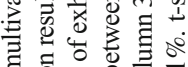

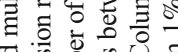

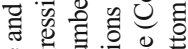

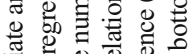

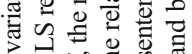

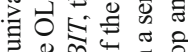

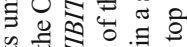

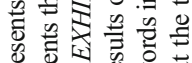

要

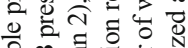

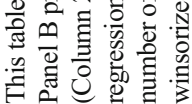


also hold negative attitudes toward female CEOs and may downplay their capabilities. This in turn may cause them to discount, or at least not appreciate, the female CEOs' forecasts despite their higher accuracy. To assess whether analysts recognize the higherquality forecasts of female CEOs, we use the following model, which focuses on the association between management earnings forecast errors and analyst earnings forecast errors and dispersions.

To test this hypothesis, we run the following OLS models:

$$
\begin{aligned}
\text { AFE } / A F \_ \text {DISP }= & \beta_{0}+\beta_{1} F C E O+\beta_{2} \text { MFE }+\beta_{3} F C E O \times \text { MFE }+\beta_{4} R O A+\beta_{5} \text { LOSS } \\
& +\beta_{6} \text { ABSCHG }+\beta_{7} \text { Volatility }+\beta_{8} \text { Distress }+\beta_{9} M B+\beta_{10} \text { Follow } \\
& +\beta_{11} \text { SIZE }+\beta_{12} \text { Big }+\beta_{13} A B S A E M+\beta_{14} A B S R E M+\beta_{15} \text { GAP_AF } \\
& +\beta_{16} I N S T \_O W N+\beta_{17} \text { LAFE } / \text { LAF_DISP }+ \text { FIRM FE }+ \text { YEAR FE }+\varepsilon
\end{aligned}
$$

In Model (6), the dependent variable is either $A F E$ or $A F \_D I S P$. AFE is the absolute value of the difference between the analyst consensus earnings forecast per share and the actual earnings per share (street earnings), divided by the stock price and then multiplied by $100 . A F \_D I S P$ is the standard deviation of the analyst forecasts per share, divided by the stock price. Our interest lies in the interaction variable FCEO $x$ MFE. A positive (negative) coefficient estimate for $\beta_{3}$ in each of the models will suggest a greater (smaller) association of analyst forecast errors and dispersions with the management forecast errors of female CEOs, and therefore greater (smaller) reliance of analysts on female CEOs' forecasts. Because analyst forecasts issued close to the earnings announcement date are likely to be more accurate, we control for the average time between the issuance of analysts' forecasts and the end of the fiscal year, GAP_AF. To account for analyst forecast consistency (Hilary and Hsu 2013), we control for the previous year's average analyst forecast errors, $L A F E$, and the previous year's average analyst forecast dispersion, $L A F \_D I S P$. All other variables are as defined in Model (2).

Table 9 reports on the association of analyst forecast errors (Column 1) and analyst forecast dispersion (Column 2) with management forecast errors. The very high correlation of the dependent variables with $M F E$ is evidence that management forecasts are an important input for analyst forecasts. We find that the coefficient of the interaction variable FCEO $\times$ MFE is positive and significant in both columns, which indicates that analyst forecast errors and forecast dispersion are more strongly correlated with the management forecast errors of female CEOs. These results are consistent with analysts placing more weight on the forecasts of female CEOs than those of male CEOs. One explanation for these results is that analysts rely more on female CEOs' forecasts when preparing their own forecasts because they recognize female CEOs' higher accuracy. However, we must acknowledge that the lower association of analyst forecast errors with the management forecast errors of male CEOs could happen if analysts who follow companies with male CEOs derive more of their information from other channels. ${ }^{24} \mathrm{We}$ also observe that analyst

\footnotetext{
${ }^{24}$ For example, it is possible that male CEOs communicate privately with financial analysts more than female CEOs do. Even though the private communication between firms and analysts is prohibited under Reg FD, some studies show that analysts continue to derive some private information from companies (Ajinkya et al. 2005; Fang and Huang 2017). Because females are deemed more ethical than men (Bernardi and Arnold 1997; Valentine and Rittenburg 2004; Lund 2008; Gupta et al. 2020), they are more likely to adhere to Reg FD and avoid the private disclosure of information to analysts.
} 
forecast errors and forecast dispersion are positively associated with $L O S S, A B S C H G$, DISTRESS, and GAP_AF.

It is realistic to expect that analysts will need to take some time to recognize the superior forecasts of female CEOs. We therefore expand Model (6) to incorporate the indicator variable FIRST, which is set to 1 for the first year the company is covered by analysts (no analyst followed the company for at least three years), and to 0 otherwise. We then interact FIRST with $M F E$ and with $M F E \times F C E O$. A negative coefficient of $F C E O$ × $M F E \times$ FIRST will suggest that the stronger reliance on the forecast of female CEOs does not occur right away, and will add credibility to our model. We report the results of the expanded model in Column 3. As can be seen, the coefficients of FCEO x MFE $\times$ FIRST are negative and significant in both columns.

\subsection{Difference-in-difference research design}

Even though we include firm fixed effects in all the models, we use a difference-indifference approach to further mitigate the correlated omitted variable problem and to ensure the robustness of our results. We first construct a treatment sample of companies that changed their CEOs from male to female, and a control sample of companies with male-to-male CEO transitions. We identify all cases of CEO transitions that meet the following criteria. First, both pre- and post-transition CEOs must be in that position consecutively for at least three years. Second, if the company has several same-gender CEO transitions (e.g., from male to male, and then from male to male again), we only keep the latest transition. Third, we exclude observations of the transition year. Fourth, there must be at least one observation pre and post transition to ensure that the sample is balanced. We include observations up to five years before and after the transition and control for CEO experience by controlling for their tenure. Under this research design, the sample size drops by more than $70 \%$. Table 10, Panel A summarizes the number of transitions and related observations for the sample and control groups separately for hypotheses $\mathrm{H} 1$ and $\mathrm{H} 2$.

Then, we construct the following difference-in-difference regression model:

$$
\begin{gathered}
\text { Dependent Variable }=\beta_{0}+\beta_{1} F \_ \text {TRANS } \times \text { POST }+\beta_{2} \text { Control Variables }+ \text { FIRM FE } \\
+ \text { YEAR FE }+\varepsilon
\end{gathered}
$$

where POST is an indicator variable equal to $1(0)$ for firm-year observations after (before) CEO transitions. $F \_$TRANS is an indicator variable equal to 1 for observations in the treatment sample (male-to-female transitions), and to 0 for observations in the control sample (male-to-male transitions). Our variable of interest is the interaction variable $F \_T R A N S \times$ POST. ${ }^{25}$ The difference-in-difference regression results are presented in Table 10, Panel B. Consistent with the $\mathrm{H} 1$ results showing that female CEOs are more likely to issue earnings forecasts, Column 1 reports a positive and significant coefficient of $F_{-}$TRANS $x$ POST, suggesting an increase in the likelihood of providing management forecasts after a transition from a male to a female $\mathrm{CEO}$, relative to a transition from a male to a male CEO. Consistent with the results of $\mathrm{H} 2$, in Column 2

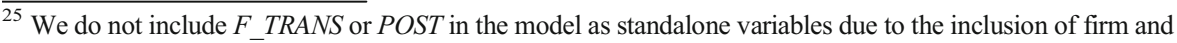
year fixed effects.
} 
Table 9 Analyst earnings forecast errors and forecast dispersion and management forecast errors

\begin{tabular}{|c|c|c|c|c|}
\hline & AFE & AF_DISP & AFE & AF_DISP \\
\hline FCEO & $\begin{array}{l}0.063 \\
(1.030)\end{array}$ & $\begin{array}{l}-0.017 \\
(-0.267)\end{array}$ & $\begin{array}{l}0.043 \\
(0.657)\end{array}$ & $\begin{array}{l}-0.008 \\
(-0.128)\end{array}$ \\
\hline MFE & $\begin{array}{l}0.323^{* * *} \\
(20.472)\end{array}$ & $\begin{array}{l}0.172^{* * * *} \\
(11.826)\end{array}$ & $\begin{array}{l}0.320^{\text {**** }} \\
(21.375)\end{array}$ & $\begin{array}{l}0.180^{* * *} \\
(12.947)\end{array}$ \\
\hline FCEO x MFE & $\begin{array}{l}0.161^{\text {**** }} \\
(3.817)\end{array}$ & $\begin{array}{l}0.115^{*} \\
(1.889)\end{array}$ & $\begin{array}{l}0.149^{* * * *} \\
(4.031)\end{array}$ & $\begin{array}{l}0.109^{* *} \\
(2.059)\end{array}$ \\
\hline FIRST & & & $\begin{array}{l}0.036 \\
(0.723)\end{array}$ & $\begin{array}{l}-0.093^{* *} \\
(-2.159)\end{array}$ \\
\hline FCEO x FIRST & & & $\begin{array}{l}0.296 \\
(1.004)\end{array}$ & $\begin{array}{l}0.090 \\
(0.323)\end{array}$ \\
\hline MFE x FIRST & & & $\begin{array}{l}-0.021 \\
(-0.506)\end{array}$ & $\begin{array}{l}0.064^{* *} \\
(2.116)\end{array}$ \\
\hline FCEO $x$ MFE $x$ FIRST & & & $\begin{array}{l}-0.390^{* * * *} \\
(-4.519)\end{array}$ & $\begin{array}{l}-0.339^{\text {*** }} \\
(-2.650)\end{array}$ \\
\hline $\mathrm{ROA}$ & $\begin{array}{l}0.060 \\
(0.205)\end{array}$ & $\begin{array}{l}0.191 \\
(0.609)\end{array}$ & $\begin{array}{l}0.019 \\
(0.066)\end{array}$ & $\begin{array}{l}0.289 \\
(0.984)\end{array}$ \\
\hline LOSS & $\begin{array}{l}0.096^{* *} \\
(2.127)\end{array}$ & $\begin{array}{l}0.279^{* * * *} \\
(5.474)\end{array}$ & $\begin{array}{l}0.097^{* *} \\
(2.177)\end{array}$ & $\begin{array}{l}0.295^{* * *} \\
(5.987)\end{array}$ \\
\hline ABSCHG & $\begin{array}{l}0.488^{* * *} \\
(3.072)\end{array}$ & $\begin{array}{l}0.764^{* * * *} \\
(4.707)\end{array}$ & $\begin{array}{l}0.509^{* * *} \\
(3.408)\end{array}$ & $\begin{array}{l}0.682^{* * *} \\
(4.482)\end{array}$ \\
\hline VOLATILITY & $\begin{array}{l}0.469 \\
(1.436)\end{array}$ & $\begin{array}{l}2.042^{* * * *} \\
(6.388)\end{array}$ & $\begin{array}{l}0.416 \\
(1.344)\end{array}$ & $\begin{array}{l}1.987^{* * *} \\
(6.529)\end{array}$ \\
\hline DISTRESS & $\begin{array}{l}0.027^{* * *} \\
(1.983)\end{array}$ & $\begin{array}{l}0.034^{* *} \\
(2.314)\end{array}$ & $\begin{array}{l}0.030^{* *} \\
(2.070)\end{array}$ & $\begin{array}{l}0.040^{* *} \\
(2.536)\end{array}$ \\
\hline MB & $\begin{array}{l}-0.001 \\
(-0.794)\end{array}$ & $\begin{array}{l}-0.003 \\
(-1.440)\end{array}$ & $\begin{array}{l}-0.001 \\
(-0.757)\end{array}$ & $\begin{array}{l}-0.003 \\
(-1.524)\end{array}$ \\
\hline FOLLOW & $\begin{array}{l}-0.009^{\text {**** }} \\
(-4.110)\end{array}$ & $\begin{array}{l}0.001 \\
(0.429)\end{array}$ & $\begin{array}{l}-0.009^{* * *} \\
(-4.339)\end{array}$ & $\begin{array}{l}-0.000 \\
(-0.172)\end{array}$ \\
\hline SIZE & $\begin{array}{l}-0.022 \\
(-1.032)\end{array}$ & $\begin{array}{l}0.034 \\
(1.264)\end{array}$ & $\begin{array}{l}-0.019 \\
(-0.871)\end{array}$ & $\begin{array}{l}0.015 \\
(0.593)\end{array}$ \\
\hline BIG & $\begin{array}{l}0.032 \\
(0.404)\end{array}$ & $\begin{array}{l}-0.062 \\
(-0.788)\end{array}$ & $\begin{array}{l}-0.000 \\
(-0.002)\end{array}$ & $\begin{array}{l}-0.110 \\
(-1.423)\end{array}$ \\
\hline ABSAEM & $\begin{array}{l}0.267 \\
(1.060)\end{array}$ & $\begin{array}{l}0.067 \\
(0.242)\end{array}$ & $\begin{array}{l}0.159 \\
(0.652)\end{array}$ & $\begin{array}{l}-0.151 \\
(-0.560)\end{array}$ \\
\hline ABSREM & $\begin{array}{l}-0.150 \\
(-0.730)\end{array}$ & $\begin{array}{l}-0.002 \\
(-0.008)\end{array}$ & $\begin{array}{l}-0.145 \\
(-0.759)\end{array}$ & $\begin{array}{l}0.016 \\
(0.070)\end{array}$ \\
\hline GAP_AF & $\begin{array}{l}0.477^{* * *} \\
(5.388)\end{array}$ & $\begin{array}{l}0.709^{* * * *} \\
(8.269)\end{array}$ & $\begin{array}{l}0.509^{* * * *} \\
(5.810)\end{array}$ & $\begin{array}{l}0.719^{* * *} \\
(8.809)\end{array}$ \\
\hline INST_OWN & $\begin{array}{l}-0.011 \\
(-0.231)\end{array}$ & $\begin{array}{l}-0.077 \\
(-1.405)\end{array}$ & $\begin{array}{l}-0.056 \\
(-1.171)\end{array}$ & $\begin{array}{l}-0.127^{* *} \\
(-2.285)\end{array}$ \\
\hline LAFE & $\begin{array}{l}0.007 \\
(0.337)\end{array}$ & & & \\
\hline
\end{tabular}


Table 9 (continued)

\begin{tabular}{lllll}
\hline & AFE & AF_DISP & AFE & AF_DISP \\
\hline LAF_DISP & & 0.032 & & \\
& & $(1.323)$ & & \\
Intercept & $0.360^{*}$ & -0.164 & $0.415^{* *}$ & 0.113 \\
& $(1.832)$ & $(-0.689)$ & $(2.040)$ & $(0.504)$ \\
Firm FE & YES & YES & YES & YES \\
Year FE & YES & YES & YES & YES \\
Adj. R-Sq. & 0.694 & 0.603 & 0.682 & 0.605 \\
$\mathrm{~N}$ & 12,896 & 12,618 & 13,888 & 13,662 \\
\hline
\end{tabular}

This table presents the OLS regression results of Model (6) in Columns (1) and (2), respectively. The dependent variable in Column (1) is $A F E$, the absolute average forecast errors of the analysts, divided by the stock price and multiplied by 100 . The dependent variable in Column (2) is $A F \_D I S P$, the standard deviation of analyst forecasts, divided by the stock price (analyst earnings forecast dispersion). The independent variable of interest is the interaction of the management forecast error with CEO gender, FCEO x MFE. In Columns (3) and (4), we report the results for the expanded Model (6), which adds FIRST, an indicator variable equal to 1 for the first year a company is covered by analysts (no analyst follows the company in the previous three years), and to 0 otherwise, and its interaction term with FCEO and MFE. Our variable of interest in Columns (3) and (4) is FCEO $\times$ MFE x FIRST. Firm and year fixed effects are included in both models. Variable definitions are shown in the Appendix. All continuous variables are winsorized at the top and bottom $1 \%$. t-statistics are reported in parentheses, and ${ }^{* * *},{ }^{* *}$, and ${ }^{*}$ denote significance at the $1 \%, 5 \%$, and $10 \%$ levels, respectively

the coefficient of $F \_$TRANS $x$ POST is negative and significant, suggesting a decrease in management forecast errors after a male-to-female CEO transition, relative to a maleto-male CEO transition. Overall, the difference-in-difference regression results are consistent with our results on forecasts by female CEOs.

\subsection{Propensity score matching and entropy balancing}

As a robustness check, we use both propensity score-matching (PSM) and entropybalancing methods in a further attempt to rule out the impacts of confounding effects. For the PSM procedure, we match female CEO observations with the nearest 10 male CEO observations within a distance of 0.05 . Observations are matched on the firm characteristics controlled in Models (1) and (2), industry and year. We also use the entropy-balancing method to construct a balanced sample. All observations with male CEOs are reweighted to match observations with female CEOs, based on the same variables used in PSM. Then, we rerun Models (1) and (2) with the matched samples generated by PSM and entropy balancing. Columns (1) and (2) of Table 11, Panel A report the results of the sample matched on propensity scores. Columns (3) and (4) present the results of using the entropy-balancing approach. Our variable of interest, $F C E O$, continues to yield a positive coefficient when testing $\mathrm{H} 1$ and a negative coefficient when testing $\mathrm{H} 2$. We check the rebalancing of the matched samples after PSM and report the results in Panels B and C. The results show that there is no significant difference in firm characteristics between observations with female CEOs and male CEOs, which indicates that the PSM-matched samples are well balanced. 
Table 10 Difference-in-difference research design

\section{Panel A: Transition Matrix}

Hypothesis

H1

$\mathrm{H} 2$

Transition Type

From male CEO to female CEO

From male CEO to male CEO

From male CEO to female CEO

From male CEO to male CEO

Panel B: Difference-in-Difference Results

\begin{tabular}{ll} 
& MF \\
F_TRANS X POST & $\mathbf{0 . 0 5 3}^{\text {****}}$ \\
\multirow{2}{*}{ ROA } & $\mathbf{( 2 . 6 2 7 )}$ \\
& -0.033 \\
& $(-1.022)$ \\
LOSS & $-0.052^{* * * *}$ \\
& $(-5.446)$ \\
NEGCHG & 0.004 \\
& $(0.761)$
\end{tabular}

ABSCHG

VOLATILITY

DISTRESS

MB

FOLLOW

SIZE

BIG

GAP_MF

ABSAEM

ABSREM

$-0.115^{\text {** }}$

$(-2.280)$

$-0.013^{\text {**** }}$

$(-2.920)$

0.001

(1.140)

$0.006^{* * *}$

(4.837)

$0.064^{\text {*** }}$

(7.212)

$0.047^{* * *}$

(2.961)

$2.354^{\text {*** }}$

(4.151)

$3.960^{*}$

(1.821)

0.021

(0.319)

0.002

(0.264)

$-0.032^{\text {*** }}$

$(-3.552)$

$-0.285^{\text {*** }}$

$(-2.100)$

0.314

(0.440)

$2.001^{* * * *}$

(7.603)

0.191

(0.164)

$1.604^{*}$

(1.753)

$-0.099$

$(-0.420)$

$-0.013$

$(-1.397)$

2.067

(1.533)

YES

$\begin{array}{lll}\text { INST_OWN } & -0.020 & -0.099 \\ & (-0.925) & (-0.420) \\ \text { TENURE } & 0.002^{*} & -0.013 \\ & (1.812) & (-1.397) \\ \text { Intercept } & -0.184^{* * *} & 2.067 \\ & (-2.908) & (1.533) \\ \text { Firm FE } & \text { YES } & \text { YES }\end{array}$

Observations

770

12,206

296

3660 
Table 10 (continued)

\begin{tabular}{lll}
\hline \hline Year FE & YES & YES \\
Adj. R-Sq. & 0.669 & 0.444 \\
$\mathrm{~N}$ & 12,976 & 3953 \\
\hline
\end{tabular}

This table presents the results related to the difference-in-difference tests. Panel A reports the number of CEO transitions and related observations from male-to-female CEOs and from male-to-male CEOs separately. Panel B presents the results of the difference-in-difference regression models for $\mathrm{H} 1$ and $\mathrm{H} 2$. The independent variable of interest is the interaction of the indicator variable for male-to-female CEO transitions with an indicator variable for the post-CEO transition, F_TRANS x POST. Variable definitions are provided in the Appendix. All continuous variables are winsorized at the top and bottom 1\%. Significance at the 10\%, 5\%, and $1 \%$ levels is indicated by $* * *$, and ***, respectively

\subsection{Alternative explanation for $\mathrm{H} 2$}

Studies have shown that, on average, managers issue pessimistic quarterly earnings forecasts (Matsumoto 2002; Kross et al. 2011). Thus, an alternative explanation for the smaller management forecast errors of female CEOs (H2) is that male CEOs (more often than female CEOs) strategically choose to provide pessimistic earnings forecasts. Doing so will increase the likelihood of beating their forecasts, allowing those managers to establish reputations as capable CEOs who exceed expectations. If this practice is more common among male CEOs than among female CEOs, it will lead to higher management forecast errors by male CEOs. To rule out this possibility, we construct the dependent variable, $B E A T$, which is set to 1 if the actual earnings exceed the manager's forecast. We then regress $B E A T$ on $F C E O$ and the other controls. The results reported in Table 12 show that the coefficient of FCEO is insignificant (t-value = $-1.002)$. This finding suggests that there is no gender difference in the likelihood of actual earnings exceeding forecasted earnings, which rules out the alternative explanation.

\subsection{Other robustness tests}

Glass cliff theory predicts that female executives are more likely to be promoted to leadership positions in companies that are struggling and have a high risk of failure (e.g., Ryan and Haslam 2007; Cook and Glass 2014). Regardless of their gender, CEOs of sinking ships may work harder to gain the attention and trust of analysts and investors. If female CEOs are more likely to be selected to run sinking ships, and if the CEOs of sinking ships make greater efforts to provide high quality earnings forecasts, then the higher quality earnings forecasts of female CEOs could be due to the types of companies they lead rather than to their greater efforts. We therefore compare company performance prior to male-to-female CEO transitions and maleto-male CEO transitions. As shown in Table 13, female CEOs are more likely to be hired by larger companies and companies whose monthly stock returns are less volatile. The results of the financial performance and stock market performance for the three years before the CEO transitions show that the return on assets, ROA, and the market-adjusted abnormal return, $A R$, of companies with male-to-female transitions are similar to those of companies with male-to-male transitions. For the other firm characteristics we examine (LOSS, VOLATILITY, DISTRESS, and MB), the 
Table 11 PSM and entropy-balancing approaches

Panel A: Results with Matched Sample

\begin{tabular}{|c|c|c|c|c|}
\hline \multirow{4}{*}{ FCEO } & \multicolumn{2}{|l|}{ PSM } & \multicolumn{2}{|c|}{ Entropy Balancing } \\
\hline & MF & MFE & $\mathrm{MF}$ & MFE \\
\hline & $0.032^{*}$ & $-0.901^{*}$ & $0.049^{* * * *}$ & $-0.521^{*}$ \\
\hline & (1.659) & $(-1.840)$ & (3.860) & $(-1.710)$ \\
\hline \multirow[t]{2}{*}{$\mathrm{ROA}$} & 0.010 & -2.646 & 0.010 & -2.894 \\
\hline & $(0.248)$ & $(-0.939)$ & $(0.317)$ & $(-1.425)$ \\
\hline \multirow[t]{2}{*}{ LOSS } & $-0.079^{* * *}$ & 0.387 & $-0.074^{* * *}$ & $0.511^{*}$ \\
\hline & $(-5.078)$ & (1.089) & $(-6.127)$ & (1.883) \\
\hline \multirow[t]{2}{*}{ NEGCHG } & $0.016^{*}$ & & $0.015^{* *}$ & \\
\hline & $(1.715)$ & & $(2.116)$ & \\
\hline \multirow[t]{2}{*}{ ABSCHG } & & $1.984^{* * *}$ & & $1.978^{* * * *}$ \\
\hline & & $(2.801)$ & & $(3.430)$ \\
\hline \multirow[t]{2}{*}{ VOLATILITY } & -0.095 & 2.472 & -0.086 & 3.218 \\
\hline & $(-1.351)$ & $(0.571)$ & $(-1.595)$ & (1.123) \\
\hline \multirow[t]{2}{*}{ DISTRESS } & 0.003 & 0.031 & 0.000 & 0.003 \\
\hline & $(0.459)$ & $(0.206)$ & $(0.075)$ & $(0.023)$ \\
\hline \multirow[t]{2}{*}{ MB } & -0.001 & 0.006 & -0.001 & 0.002 \\
\hline & $(-0.885)$ & $(0.520)$ & $(-1.116)$ & $(0.256)$ \\
\hline \multirow[t]{2}{*}{ FOLLOW } & $0.008^{* * *}$ & -0.001 & $0.008^{\text {***** }}$ & -0.005 \\
\hline & (4.284) & $(-0.090)$ & $(5.484)$ & $(-0.409)$ \\
\hline \multirow[t]{2}{*}{ SIZE } & $0.037^{* * *}$ & -0.111 & $0.037^{* * *}$ & -0.068 \\
\hline & (3.087) & $(-0.489)$ & $(4.028)$ & $(-0.480)$ \\
\hline \multirow[t]{2}{*}{ BIG } & -0.010 & -0.184 & -0.002 & -0.254 \\
\hline & $(-0.581)$ & $(-0.524)$ & $(-0.170)$ & $(-0.842)$ \\
\hline \multirow[t]{2}{*}{ INST_OWN } & -0.007 & -0.254 & 0.009 & -0.242 \\
\hline & $(-0.229)$ & $(-0.781)$ & $(0.373)$ & $(-1.104)$ \\
\hline \multirow[t]{2}{*}{ ABSAEM } & & $1.967^{*}$ & & $1.901^{* *}$ \\
\hline & & (1.769) & & (2.249) \\
\hline \multirow[t]{2}{*}{ ABSREM } & & -0.116 & & -0.220 \\
\hline & & $(-0.090)$ & & $(-0.232)$ \\
\hline \multirow[t]{2}{*}{ GAP_MF } & & $2.131^{* * * *}$ & & $2.288^{* * *}$ \\
\hline & & (5.643) & & (8.381) \\
\hline \multirow[t]{2}{*}{ Intercept } & 0.060 & 1.589 & 0.028 & 0.998 \\
\hline & $(0.796)$ & $(0.929)$ & $(0.509)$ & $(0.916)$ \\
\hline Firm FE & YES & YES & YES & YES \\
\hline Year FE & YES & YES & YES & YES \\
\hline Adj. R-Sq. & 0.658 & 0.438 & 0.683 & 0.545 \\
\hline $\mathrm{N}$ & 13,119 & 3831 & 49,595 & 13,888 \\
\hline
\end{tabular}


Table 11 (continued)

\begin{tabular}{|c|c|c|c|c|c|c|c|}
\hline \multicolumn{8}{|c|}{ Panel B: Balancing test of PSM H1 Sample } \\
\hline & Mean & & & & & t-test & \\
\hline Variable & $\mathrm{N}$ & Female CEO & $\mathrm{N}$ & Male CEO & $\%$ Bias & $\mathrm{t}$ & $\mathrm{p}>\mathrm{t}$ \\
\hline ROA & 1561 & -0.048 & 11,558 & -0.045 & -0.900 & -0.260 & 0.797 \\
\hline LOSS & 1561 & 0.340 & 11,558 & 0.330 & 2.100 & 0.580 & 0.564 \\
\hline NEGCHG & 1561 & 0.431 & 11,558 & 0.431 & 0.000 & 0.010 & 0.995 \\
\hline VOLATILITY & 1561 & 0.132 & 11,558 & 0.131 & 2.100 & 0.580 & 0.561 \\
\hline DISTRESS & 1561 & -2.966 & 11,558 & -2.985 & 1.100 & 0.300 & 0.765 \\
\hline MB & 1561 & 3.394 & 11,558 & 3.395 & 0.000 & -0.010 & 0.996 \\
\hline FOLLOW & 1561 & 9.327 & 11,558 & 9.416 & -1.000 & -0.280 & 0.776 \\
\hline SIZE & 1561 & 6.401 & 11,558 & 6.441 & -2.000 & -0.540 & 0.592 \\
\hline BIG & 1561 & 0.810 & 11,558 & 0.812 & -0.400 & -0.110 & 0.912 \\
\hline INST_OWN & 1561 & 0.464 & 11,558 & 0.469 & -1.500 & -0.420 & 0.677 \\
\hline \multicolumn{8}{|c|}{ Panel C: Balancing test of PSM H2 Sample } \\
\hline & Mean & & & & & t-test & \\
\hline Variable & $\mathrm{N}$ & Female CEO & $\mathrm{N}$ & Male CEO & $\%$ Bias & $\mathrm{t}$ & $\mathrm{p}>\mathrm{t}$ \\
\hline ROA & 488 & 0.055 & 3343 & 0.056 & -0.800 & -0.120 & 0.903 \\
\hline LOSS & 488 & 0.119 & 3343 & 0.116 & 0.800 & 0.120 & 0.905 \\
\hline ABSCHG & 488 & 0.073 & 3343 & 0.070 & 1.100 & 0.170 & 0.867 \\
\hline VOLATILITY & 488 & 0.097 & 3343 & 0.096 & 1.500 & 0.220 & 0.822 \\
\hline DISTRESS & 488 & -3.353 & 3343 & -3.352 & -0.100 & -0.020 & 0.985 \\
\hline MB & 488 & 4.019 & 3343 & 3.695 & 6.200 & 0.920 & 0.356 \\
\hline FOLLOW & 488 & 13.779 & 3343 & 13.945 & -2.000 & -0.310 & 0.758 \\
\hline SIZE & 488 & 7.661 & 3343 & 7.757 & -5.400 & -0.830 & 0.409 \\
\hline BIG & 488 & 0.965 & 3343 & 0.970 & -2.400 & -0.370 & 0.708 \\
\hline ABSAEM & 488 & 0.042 & 3343 & 0.041 & 3.300 & 0.490 & 0.624 \\
\hline ABSREM & 488 & 0.053 & 3343 & 0.051 & 3.500 & 0.530 & 0.594 \\
\hline INST_OWN & 488 & 0.512 & 3343 & 0.501 & 2.600 & 0.400 & 0.688 \\
\hline
\end{tabular}

This table presents the results of the balanced samples generated by propensity score matching (PSM) and entropy balancing. Panel A reports the regression results of Models (1) and (2) with the matched samples. The results of the matched sample based on PSM are reported in Columns (1) and (2), and the results of the balanced sample generated by entropy balancing are reported in Columns (3) and (4). Both firm and year fixed effects are included. Panels B and C present the results of the balancing tests of the sample matched on propensity scores. Variable definitions are shown in the Appendix. All continuous variables are winsorized at the top and bottom $1 \%$. t-statistics are reported in parentheses, and ${ }^{* * *},{ }^{* *}$, and ${ }^{*}$ denote significance at the $1 \%, 5 \%$, and $10 \%$ levels, respectively

results show no significant difference between firms hiring female CEOs and firms hiring male CEOs. Thus, we conclude that female CEOs are not hired by companies under financial distress.

CFOs also play an important role in the provision of earnings forecasts (e.g., Bamber et al. 2010). A potential explanation for our results is that the differences in earnings forecasts are driven by gender differences involving the CFO. Given that controlling for $\mathrm{CFO}$ gender will reduce our sample size by approximately $40 \%$, we report the 
Table 12 Beating management earnings forecast by CEO gender

\begin{tabular}{|c|c|c|}
\hline & FCEO & $\begin{array}{l}-0.036 \\
(-1.002)\end{array}$ \\
\hline & ROA & $0.303^{* * *}$ \\
\hline & & $(3.948)$ \\
\hline & LOSS & $-0.050^{* * * *}$ \\
\hline & & $(-2.841)$ \\
\hline & ABSCHG & 0.031 \\
\hline & & $(1.405)$ \\
\hline & VOLATILITY & -0.014 \\
\hline & & $(-0.126)$ \\
\hline & DISTRESS & -0.010 \\
\hline & & $(-1.269)$ \\
\hline & MB & $0.005^{* * *}$ \\
\hline & & $(4.023)$ \\
\hline & FOLLOW & $-0.006^{* * *}$ \\
\hline & & $(-4.287)$ \\
\hline & SIZE & -0.022 \\
\hline & & $(-1.622)$ \\
\hline & BIG & -0.030 \\
\hline & & $(-0.874)$ \\
\hline This table presents the OLS re- & GAP_MF & $-0.215^{* * *}$ \\
\hline gression results of the likelihood & & $(-8.339)$ \\
\hline $\begin{array}{l}\text { of the actual earnings exceeding } \\
\text { the manager's forecasted earnings }\end{array}$ & ABSAEM & -0.030 \\
\hline by CEO gender. The dependent & & $(-0.238)$ \\
\hline variable is $B E A T$, an indicator & ABSREM & $0.304^{* * * *}$ \\
\hline variable equal to 1 if the actual & & $(2.972)$ \\
\hline earnings exceed the manager's & INST_OWN & $-0.067^{* *}$ \\
\hline $\begin{array}{l}\text { earnings forecast, and to } 0 \text { other- } \\
\text { wise. Both firm and year fixed }\end{array}$ & & $(-2.361)$ \\
\hline effects are included. Variable & Intercept & $0.738^{* * * *}$ \\
\hline definitions are shown in the Ap- & & $(6.593)$ \\
\hline $\begin{array}{l}\text { pendix. All continuous variables } \\
\text { are winsorized at the ton and }\end{array}$ & Firm FE & YES \\
\hline bottom $1 \%$. t-statistics are report- & Year FE & YES \\
\hline ed in parentheses, and ${ }^{* * *},{ }^{* *}$, and & Adj. R-Sq. & 0.135 \\
\hline "denote significance at the $1 \%$, & $\mathrm{N}$ & 13,888 \\
\hline
\end{tabular}

regression results after controlling for the CFO's gender $(F C F O)$ as a robustness test. In untabulated results, we find that $F C F O$ is insignificant in the tests of $\mathrm{H} 1$ and $\mathrm{H} 2$, and its interaction with $M F E$ is insignificant in the test of $\mathrm{H} 3$. At the same time, our results for FCEO are consistent with those previously reported. These results indicate that the association between female CEOs and earnings forecasts cannot be attributed to the CFO's gender, and reinforce the idea that CEOs play a decisive role in the provision of earnings forecasts. 
Table 13 Firm performance in the year prior to CEO change by CEO gender

\begin{tabular}{|c|c|c|c|c|c|c|c|c|}
\hline & \multicolumn{3}{|c|}{ Male CEOs } & \multicolumn{3}{|c|}{ Female CEOs } & \multicolumn{2}{|c|}{ Mean difference } \\
\hline & $\mathrm{N}$ & Mean & STD & $\mathrm{N}$ & Mean & STD & Difference & T-statistics \\
\hline AVG_ROA & 1654 & -0.011 & 0.194 & 105 & 0.013 & 0.134 & -0.024 & -1.241 \\
\hline ROA_Y3 & 1342 & -0.001 & 0.204 & 86 & 0.021 & 0.158 & -0.022 & -0.977 \\
\hline ROA_Y2 & 1525 & 0.001 & 0.200 & 97 & 0.019 & 0.159 & -0.018 & -0.885 \\
\hline ROA_Y1 & 1654 & -0.015 & 0.209 & 105 & 0.008 & 0.152 & -0.023 & -1.101 \\
\hline AVG_AR & 1654 & 0.087 & 0.349 & 105 & 0.054 & 0.311 & 0.032 & 0.928 \\
\hline AR_Y3 & 1342 & 0.160 & 0.636 & 86 & 0.122 & 0.638 & 0.038 & 0.541 \\
\hline AR_Y2 & 1525 & 0.098 & 0.510 & 97 & 0.213 & 0.606 & $-0.115^{* *}$ & -2.127 \\
\hline AR_Y1 & 1654 & 0.011 & 0.443 & 105 & 0.017 & 0.470 & -0.006 & -0.139 \\
\hline LOSS & 1654 & 0.288 & 0.453 & 105 & 0.257 & 0.439 & 0.031 & 0.674 \\
\hline VOLATILITY & 1654 & 0.123 & 0.081 & 105 & 0.109 & 0.065 & $0.014 *$ & 1.770 \\
\hline DISTRESS & 1654 & -2.991 & 1.545 & 105 & -3.168 & 1.373 & 0.177 & 1.143 \\
\hline MB & 1654 & 2.844 & 4.482 & 105 & 3.523 & 6.339 & -0.679 & -1.463 \\
\hline SIZE & 1654 & 6.766 & 1.997 & 105 & 7.255 & 1.980 & $-0.488 * *$ & -2.430 \\
\hline
\end{tabular}

This table presents comparative data on firm performance in the years prior to male-to-female CEO transitions and male-to-male CEO transitions. Variable definitions are shown in the Appendix. All continuous variables are winsorized at the top and bottom $1 \% .^{* * *},{ }^{* *}$, and ${ }^{*}$ denote statistical significance at the $1 \%, 5 \%$, and $10 \%$ levels, respectively

To rule out the possible impacts of other CEOs' individual characteristics, we control for CEO age and network size. As the inclusion of these variables greatly erodes the sample size, we do not include them in the main tests. In the untabulated results, the coefficients of $F C E O$ remain significant after controlling for CEO age and network size.

\section{Conclusion}

In this paper, we examine the voluntary disclosures of female CEOs, which until recently have received very little attention in the literature. In particular, we focus on management earnings forecasts, a major channel involving the communication of voluntary information (Hirst et al. 2008; Hilary and Hsu 2011). We consider not only the intrinsic traits of women but also the unfavorable views and high scrutiny from shareholders and other parties that female CEOs face, which may lead them to behave differently than male CEOs with regard to earnings forecasts.

Using a research design that includes firm and year fixed effects, we find that, compared to their male counterparts, female CEOs are more likely to provide earnings forecasts. We also show that their forecasts are significantly more accurate than those of male CEOs. These results suggest that female CEOs improve the disclosure environment of their companies by providing high-quality earnings forecasts. We also find that, on average, analysts are less likely to follow companies led by female CEOs, which is an unfavorable outcome for those CEOs, given the many benefits of enhanced 
analyst coverage. However, we show that the greater efforts that female CEOs put into forecasting accurate earnings pay off by helping them increase analyst coverage. We provide supplementary evidence that female CEOs make other efforts to provide valuable information to investors and analysts. We show that they provide more frequent earnings forecast updates until later in the year. They also provide $10-\mathrm{K}$ disclosures that are longer, contain more exhibits, and use more unique words. Finally, we find that financial analysts rely more on the management forecasts of female CEOs than on those of male CEOs when formulating their forecasts. One possible interpretation of this result is that financial analysts recognize the superior accuracy of earnings forecasts issued by female CEOs. To this end, we show that analysts' greater reliance on management forecasts does not begin right from the beginning, which suggests that analysts gradually recognize the superior performance of female CEOs. Our results are robust to numerous robustness tests and alternative research design methods, including a difference-in-difference research design, PSM, and entropy balancing.

\section{Appendix: Variable Definitions}

\begin{tabular}{|c|c|}
\hline Variable name & Definition \\
\hline \multicolumn{2}{|l|}{ Main variables } \\
\hline FCEO & $\begin{array}{l}\text { An indicator variable equal to } 1 \text { when the CEO is a female, and to } 0 \text { when the CEO is a } \\
\text { male. }\end{array}$ \\
\hline MF & $\begin{array}{l}\text { An indicator variable equal to } 1 \text { when the company issues annual earnings forecasts, } \\
\text { and to } 0 \text { otherwise. }\end{array}$ \\
\hline MFE & $\begin{array}{l}\text { Management earnings forecast error, measured as the absolute difference between the } \\
\text { management earnings forecast per share and the actual earnings per share (street } \\
\text { earnings), divided by the stock price and multiplied by } 100 \text {. }\end{array}$ \\
\hline FOLLOW & The number of analysts following the company. \\
\hline LEAD_FOLLOW & The number of analysts following the company in the subsequent year. \\
\hline LOW_MFE & $\begin{array}{l}\text { An indicator variable equal to } 1 \text { if the company provides a management forecast and } \\
\text { the MFE is below the sample median, and to } 0 \text { otherwise. }\end{array}$ \\
\hline HIGH_MFE & $\begin{array}{l}\text { An indicator variable equal to } 1 \text { if the company provides a management forecast and } \\
\text { the MFE is above the sample median, and to } 0 \text { otherwise. }\end{array}$ \\
\hline \multicolumn{2}{|l|}{ Other variables } \\
\hline ROA & Return on assets, measured as net income divided by total assets. \\
\hline ADJROA & $\begin{array}{l}\text { Average ranked industry-adjusted ROA for the previous (up to) three years for the } \\
\text { same CEO. }\end{array}$ \\
\hline DEASCORE & $\begin{array}{l}\text { Firm efficiency of generating output (sales) with various inputs (cost of goods sold, } \\
\text { acquired assets, R\&D expenditures, goodwill, SG\&A expenditures, operating } \\
\text { leases, and other intangible assets), calculated using data envelopment analysis. }\end{array}$ \\
\hline LOSS & $\begin{array}{l}\text { An indicator variable equal to } 1 \text { if the firm's current earnings are negative, and to } 0 \\
\text { otherwise. }\end{array}$ \\
\hline VOLATILITY & $\begin{array}{l}\text { Stock return volatility, measured as the standard deviation of the company's monthly } \\
\text { stock returns in the previous } 12 \text { months. }\end{array}$ \\
\hline NEGCHG & $\begin{array}{l}\text { An indicator variable equal to } 1 \text { when current earnings are smaller than the previous } \\
\text { year's earnings, and to } 0 \text { otherwise. }\end{array}$ \\
\hline
\end{tabular}




\begin{tabular}{|c|c|}
\hline Variable name & Definition \\
\hline ABSCHG & $\begin{array}{l}\text { The absolute value of the difference between the current and previous annual earnings } \\
\text { per share, divided by the stock price. }\end{array}$ \\
\hline DISTRESS & Financial distress, measured using Zmijewski’s (1984) Z-Score. \\
\hline MB & The ratio of the market value per share to the book value per share. \\
\hline SIZE & Natural logarithm of total assets. \\
\hline $\mathrm{BIG}$ & $\begin{array}{l}\text { An indicator variable equal to } 1 \text { if the company is audited by a Big } \mathrm{N} \text { firm, and to } 0 \\
\text { otherwise. }\end{array}$ \\
\hline INST_OWN & The percentage of institutional ownership. \\
\hline GAP_MF & $\begin{array}{l}\text { The number of calendar days from the issuance of the management forecast to the end } \\
\text { of the fiscal year, divided by } 365 \text { (days). }\end{array}$ \\
\hline GAP_AF & $\begin{array}{l}\text { The average number of calendar days between analyst forecasts and the end of the } \\
\text { fiscal year, divided by } 365 \text { (days). }\end{array}$ \\
\hline ABSAEM & $\begin{array}{l}\text { The absolute value of performance-adjusted discretionary accruals, estimated using } \\
\text { Kothari et al.'s (2005) model. }\end{array}$ \\
\hline ABSREM & $\begin{array}{l}\text { The absolute value of the abnormal cash flow from operations, measured using } \\
\text { Roychowdhury's (2006) model. }\end{array}$ \\
\hline FREQUENCY & $\begin{array}{l}\text { The number of annual management earnings forecasts disclosed in one year, including } \\
\text { forecast revisions. }\end{array}$ \\
\hline FILESIZE & $\begin{array}{l}\text { The natural logarithm of the total number of characters in the } 10-\mathrm{K} \text { filing without } \\
\text { tables or exhibits. }\end{array}$ \\
\hline WORD & The natural logarithm of the number of words in the $10-\mathrm{K}$ filing. \\
\hline EXHIBIT & The number of exhibits in the $10-\mathrm{K}$ filing. \\
\hline UNIQUE & The natural logarithm of the number of unique words in the $10-\mathrm{K}$ filing. \\
\hline AVG_LENGTH & $\begin{array}{l}\text { Average number of words per sentences, defined as the number of words divided by } \\
\text { the number of sentences in the } 10-\mathrm{K} \text { filing. }\end{array}$ \\
\hline GUNNING_FOG & $\begin{array}{l}\text { A measure for the readability developed by Gunning (1952), calculated as } 0.4 \mathrm{x} \\
\text { (average length of sentences }+ \text { percentage of complex words). }\end{array}$ \\
\hline SMOG_FOG & $\begin{array}{l}\text { A measure for the readability developed by McLaughlin (1969). This index estimates } \\
\text { the years of education a person needs to comprehend the } 10-\mathrm{K} \text { report. }\end{array}$ \\
\hline AFE & $\begin{array}{l}\text { Analyst forecast error, measured as the difference between the analyst consensus } \\
\text { earnings forecast per share and the actual earnings per share reported (street } \\
\text { earnings), divided by the stock price and multiplied by } 100 \text {. }\end{array}$ \\
\hline AF_DISP & $\begin{array}{l}\text { The standard deviation of analyst earnings forecasts per share, divided by the stock } \\
\text { price. }\end{array}$ \\
\hline LAFE & $\begin{array}{l}\text { Average analyst forecast error in the previous year, divided by the stock price and } \\
\text { multiplied by } 100 \text {. }\end{array}$ \\
\hline LAF_DISP & Analyst forecast dispersion in the previous year. \\
\hline FIRST & $\begin{array}{l}\text { An indicator variable equal to } 1 \text { for the first year a company is covered by analysts (no } \\
\text { analyst follows the company in the previous three years), and to } 0 \text { otherwise. }\end{array}$ \\
\hline TRADE_VOL & $\begin{array}{l}\text { Annual trading volume, measured as the sum of the daily trading volume during that } \\
\text { year (in units of hundred million shares). }\end{array}$ \\
\hline F_TRANS & $\begin{array}{l}\text { An indicator variable equal to } 1 \text { for observations in the treatment sample of } \\
\text { male-to-female CEO transitions, and to } 0 \text { for observations in the control sample of } \\
\text { male-to-male CEO transitions. }\end{array}$ \\
\hline POST & $\begin{array}{l}\text { An indicator variable equal to } 1 \text { for observations after the CEO transition, and to } 0 \\
\text { otherwise. }\end{array}$ \\
\hline TENURE & The number of years the CEO has occupied that post. \\
\hline
\end{tabular}




\begin{tabular}{ll}
\hline Variable name & Definition \\
\hline BEAT & $\begin{array}{l}\text { An indicator variable equal to } 1 \text { if actual earnings exceed the manager's forecast, and } \\
\text { to } 0 \text { otherwise. } \\
\text { The average return on assets (ROA) in the } 3 \text { years prior to the CEO transition. }\end{array}$ \\
AVG_ROA & $\begin{array}{l}\text { Return on assets (ROA) in the year prior to the CEO transition. } \\
\text { ROA_Y1 } \\
\text { ROA_Y2 }\end{array}$ \\
ROA_Y3 & $\begin{array}{l}\text { Return on assets (ROA) in the second year prior to the CEO transition. } \\
\text { The average market-adjusted abnormal return (AR) in the } 3 \text { years prior to the CEO } \\
\text { transition. } \\
\text { MVG_AR }\end{array}$ \\
AR_Y1 & $\begin{array}{l}\text { Market-adjusted abnormal return in the year prior to the CEO transition. } \\
\text { MR_Y2 }\end{array}$ \\
AR_Y3 & $\begin{array}{l}\text { Market-adjusted abnormal return in the thicator variable equal to } 1 \text { when the CFO is female, and to } 0 \text { when the CFO is } \\
\text { male. }\end{array}$ \\
FCFO &
\end{tabular}

Open Access This article is licensed under a Creative Commons Attribution 4.0 International License, which permits use, sharing, adaptation, distribution and reproduction in any medium or format, as long as you give appropriate credit to the original author(s) and the source, provide a link to the Creative Commons licence, and indicate if changes were made. The images or other third party material in this article are included in the article's Creative Commons licence, unless indicated otherwise in a credit line to the material. If material is not included in the article's Creative Commons licence and your intended use is not permitted by statutory regulation or exceeds the permitted use, you will need to obtain permission directly from the copyright holder. To view a copy of this licence, visit http://creativecommons.org/licenses/by/4.0/.

\section{References}

Adams, R.B., and D. Ferriera. 2009. Women in the boardroom and their impact on governance and performance. Journal of Financial Economics 94: 291-309.

Adams, R.B., and P. Funk. 2012. Beyond the glass ceiling: Does gender matter? Management Science 58 (2): $219-235$.

Ajinkya, B., S. Bhojraj, and P. Sengupta. 2005. The association between outside directors, institutional investors and the properties of management earnings forecasts. Journal of Accounting Research 43 (3): 343-376.

Alford, A.W., and P.G. Berger. 1999. A simultaneous equations analysis of forecast accuracy, analyst following, and trading volume. Journal of Accounting, Auditing \& Finance 14 (3): 219-240.

Alqatamin, R., Z.A. Aribi, and T. Arun. 2017. The effect of CEOs' characteristics on forward-looking information. Journal of Applied Accounting Research 18 (4): 402-424.

Atkinson, S.M., S.B. Baird, and M.B. Frye. 2003. Do female mutual fund managers manage differently? Journal of Financial Research 26 (1): 1-18.

Baginski, S.P., and K.C. Rakow. 2012. Management earnings forecast disclosure policy and the cost of equity capital. Review of Accounting Studies 17: 279-321.

Baik, B., D. Farber, and S. Lee. 2011. CEO ability and management earnings forecasts. Contemporary Accounting Research 28 (5): 1645-1668.

Bamber, L., J. Jiang, and I. Wang. 2010. What's my style? The influence of top managers on voluntary corporate financial disclosure. The Accounting Review 85 (4): 1131-1162.

Barua, A., L.F. Davidson, D.V. Rama, and S. Thiruvadi. 2010. CFO gender and accruals quality. Accounting Horizons 24 (1): 25-39.

Behn, B.K., J.H. Choi, and T. Kang. 2008. Audit quality and properties of analyst earnings forecasts. The Accounting Review 83 (2): 327-349. 
Bernardi, R.A., and D.F. Arnold. 1997. An examination of moral development within public accounting by gender, staff level, and firm. Contemporary Accounting Research 14 (4): 653-668.

Bloomfield, R.J., K. Rennekamp, B. Steenhoven, and S. Stewart. 2021. Penalties for unexpected behavior: Double standards for women in finance. The Accounting Review 96 (2): 107-125.

Bøhren, Ø.Y., and R.Ø. Strøm. 2010. Governance and politics: Regulating independence and diversity in the board room. Journal of Business, Finance, and Accounting 37 (9-10): 1281-1308.

Boivie, S., S.D. Graffin, and R.J. Gentry. 2016. Understanding the direction, magnitude, and joint effects of reputation when multiple actors' reputations collide. Academy of Management Journal 59 (1): 188-206.

Bolliger, G., and M. Kast. 2007. Executive compensation and analyst guidance: The link between CEO pay and expectations management. Conflict of Interest, Corporate Governance and Financial Markets: 163167.

Bradshaw, M.T., and R.G. Sloan. 2002. GAAP versus the street: An empirical assessment of two alternative definitions of earnings. Journal of Accounting Research 40 (1): 41-66.

Branson, D.M. 2006. No seat at the T able: How corporate governance keeps women out of America's boardrooms. New York University Press.

Cao, Y., L.A. Myers, A. Tsang, and G. Yang. 2017. Management forecasts and the cost of equity capital: International evidence. Review of Accounting Studies 22: 791-838.

Catalyst. (2019). Women CEOs of the S\&P 500. https:/www.catalyst.org/research/women-ceos-of-the-sp$500 \%$

Chan, K., and A. Hameed. 2006. Stock price synchronicity and analyst coverage in emerging markets. Journal of Financial Economics 80 (1): 115-147.

Cheng, Q., and K. Lo. 2006. Insider trading and voluntary disclosures. Journal of Accounting Research 44 (5): 815-848.

Christensen, T., K. Fronk, J. Lee, and K. Nelson. (2021). Data visualization and infographics in 10-K filings. Working Paper, University of Georgia.

Cohen, B.D., and T.J. Dean. 2005. Information asymmetry and investor valuation of IPOs: Top management team legitimacy as a capital market signal. Strategic Management Journal 26 (7): 683-690.

Cook, A., and C. Glass. 2014. Above the glass ceiling: When are women and racial/ethnic minorities promoted to CEO? Strategic Management Journal 35 (7): 1080-1089.

Cook, A., and C. Glass. 2018. Women on corporate boards: Do they advance corporate social responsibility? Human Relations 71 (7): 897-924.

Cook, A., A. Esplin, C. Glass, S. Judd, and K. Olsen. (2020). Management forecasts, analyst revisions, and investor reactions: The effect of CEO gender. Working paper.

Croson, R., and U. Gneezy. 2009. Gender differences in preferences. Journal of Economic Literature 47 (2): $1-27$.

Demerjian, P., B. Lev, and S. McVay. 2012. Quantifying managerial ability: A new measure and validity tests. Management Science 58 (7): 1229-1248.

Derrien, F., and A. Kecskés. 2013. The real effects of financial shocks: Evidence from exogenous changes in analyst coverage. Journal of Finance 68 (4): 1407-1440.

Dezsö, C.L., and D.G. Ross. 2012. Does female representation in top management improve firm performance? A panel data investigation. Strategic Management Journal 33 (9): 1072-1089.

Dobbin, F., and J. Jung. 2010. Corporate board gender diversity and stock performance: The competence gap or institutional investor bias. North Carolina Law Review 89: 809-838.

Eagly, A.H., and L. Carli. 2003. The female leadership advantage: An evaluation of the evidence. The Leadership Quarterly 14: 807-834.

Eagly, A.H., and S.J. Karau. 2002. Role congruity theory of prejudice toward female leaders. Psychological Review 109 (3): 573-598.

Fang, L.H., and S. Huang. 2017. Gender and connections among wall street analysts. Review of Financial Studies 30 (9): 3305-3335.

Field, L., M. Lowry, and S. Shu. 2005. Does disclosure deter or trigger litigation? Journal of Accounting and Economics 39 (3):487-507.

Fos, V., K. Li, and M. Tsoutsoura. 2017. Do director elections matter? Review of Financial Studies 31 (4): 1499-1531.

Francis, B., I. Hasan, J.C. Park, and Q. Wu. 2015. Gender differences in financial reporting decision making: Evidence from accounting conservatism. Contemporary Accounting Research 32 (3): 1285-1318.

Francis, B.B., I. Hasan, Y. Shen, and Q. Wu. 2021. Do activist hedge funds target female CEOs? The role of CEO gender in hedge fund activism. Journal of Financial Economics 141 (1): 372-393.

Francoeur, C., R. Labelle, and B. Sinclair-Desgagné. 2008. Gender diversity in corporate governance and top management. Journal of Business Ethic 81 (1): 83-95. 
Gaughan, K., and E.B. Smith. (2016). Better in the shadows? Media coverage and market reactions to female CEO appointments. In: Academy of management proceedings (Vol. 1, p. 13997). Briarcliff Manor: Academy of Management.

Graham, J.R., C.R. Harvey, and S. Rajgopal. 2005. The economic implications of corporate financial reporting. Journal of Accounting and Economics 40 (1-3): 3-73.

Gray and Christmas, Inc. (2018). 2018 Women CEO Report. https://www.challengergray.com/tags/womenceo.

Greene, W. 2004. The behaviour of the maximum likelihood estimator of limited dependent variable models in the presence of fixed effects. The Econometrics Journal 7: 98-119.

Gul, F.A., M. Hutchinson, and K.M. Lai. 2013. Gender-diverse boards and properties of analyst earnings forecasts. Accounting Horizons 27 (3): 511-538.

Gull, A.A., M. Nekhili, H. Nagati, and T. Chtioui. 2017. Beyond gender diversity: How specific attributes of female directors affect earnings management. British Accounting Review 50 (3): 255-274.

Gunning, R. 1952. The technique of clear writing. McGraw-Hill.

Guo, L., and R.W. Masulis. 2015. Board structure and monitoring: New evidence from CEO turnovers. Review of Financial Studies 28: 2770-2811.

Gupta, V.K., S. Mortal, S. Silveri, M. Sun, and D.B. Turban. 2018. You're fired! Gender disparities in CEO dismissal. Journal of Management 46 (4): 560-582.

Gupta, V.K., S. Mortal, B. Chakrabarty, X. Guo, and D.B. Turban. 2020. CFO gender and financial statement irregularities. Academy of Management 63 (3): 802-831.

Habib, A., and M. Hossain. 2013. CEO/CFO characteristics and financial reporting quality: A review. Research in Accounting Regulation 25 (1): 88-100.

Hanlon, M., and J.L. Hoopes. 2014. What do firms do when dividend tax rates change? An examination of alternative payout responses. Journal of Financial Economics 114 (1): 105-124.

Harjoto, M., I. Laksmana, and R. Lee. 2015. Board diversity and corporate social responsibility. Journal of Business Ethics 132 (4): 641-660.

Hassell, J.M., R.H. Jennings, and D.J. Lasser. 1988. Management earnings forecasts: Their usefulness as a source of firm-specific information to security analysts. Journal of Financial Research 11 (4): 303-319.

Healy, P.M., and K.G. Palepu. 2001. Information asymmetry, corporate disclosure, and the capital markets: A review of the empirical disclosure literature. Journal of Accounting and Economics 31 (1-3): 405-440.

Heidrick and Struggles. (2012). 2012 Board of Directors Survey. https://www.yumpu.com/en/document/read/ 31072332/2012-board-of-directors-survey-heidrick-struggles.

Heilman, M.E., A.S. Wallen, D. Fuchs, and M. Tamkins. 2004. Penalties for success: Reactions to women who succeed at male gender-typed tasks. Journal of Applied Psychology 89 (3): 416-427.

Helgesen, S. 1990. The Female Advantage: Women's Ways of Leadership. Doubleday Currency, New York, N.Y.

Hilary, G., and C. Hsu. 2011. Endogenous overconfidence in managerial forecasts. Journal of Accounting and Economics 51: 300-313.

Hilary, G., and C. Hsu. 2013. Analyst forecast consistency. Journal of Finance 68 (1): 271-297.

Hilary, G., C. Hsu, and R. Wang. 2014. Management forecast consistency. Journal of Accounting Research 52 (1): $163-191$.

Hirst, D.E., L. Koonce, and J. Miller. 1999. The joint effect of management's prior forecast accuracy and the form of its financial forecasts on investor judgment. Journal of Accounting Research 37: 101-124.

Hirst, D.E., L. Koonce, and S. Venkataraman. 2008. Management earnings forecasts: A review and framework. Accounting Horizons 22: 315-338.

Ho, S.S., A.Y. Li, K. Tam, and F. Zhang. 2015. CEO gender, ethical leadership, and accounting conservatism. Journal of Business Ethics 127 (2): 351-370.

Hong, H., and J.D. Kubik. 2003. Analyzing the analysts: Career concerns and biased earnings forecasts. Journal of Finance 58 (1): 313-351.

Huang, J., and D.J. Kisgen. 2013. Gender and corporate finance: Are male executives overconfident relative to female executives? Journal of Financial Economics 108 (3): 822-839.

Hutcher, M., and W. Latham. 2020. States are leading the charge to corporate boards: Diversify! Forum on Corporate Governance.

Irvine, P. 2003. The incremental impact of analyst initiation of coverage. Journal of Corporate Finance 9 (4): $431-451$.

Isidro, H., and M. Sobral. 2015. The effects of women on corporate boards on firm value, financial performance, and ethical and social compliance. Journal of Business Ethics 132 (1): 1-19.

Jeong, S., and D. Harrison. 2017. Glass breaking, strategy making, and value creation: Meta-analytic outcome of women as CEOs and TMT members. Academy of Management Journal 66 (4): 1219-1252. 
Kanter, R.M. 1977. Men and women of the corporation. Basic Books.

Kim, J.B. 2016. Accounting flexibility and managers' forecast behavior prior to seasoned equity offerings. Review of Accounting Studies 21: 1361-1400.

Kimbrough, M.D., and H. Louis. 2011. Voluntary disclosure to influence investor reactions to merger announcements: An examination of conference calls. The Accounting Review 86 (2): 637-667.

Knippen, J.M., J. Palar, and R.J. Gentry. 2018. Breaking the mold: An examination of board discretion in female CEO appointments. Journal of Business Research 84: 11-23.

Kothari, S.P., A.J. Leone, and C.E. Wasley. 2005. Performance matched discretionary accrual measures. Journal of Accounting and Economics 39 (1): 163-197.

Kross, W., B. Ro, and I. Suk. 2011. Consistency in meeting or beating earnings expectations and management earnings forecasts. Journal of Accounting and Economics 51: 37-57.

Lang, M., and R.J. Lundholm. 1993. Cross-sectional determinants of analyst ratings of corporate disclosures. Journal of Accounting Research 31 (2): 246-271.

Lang, M.H., and R.J. Lundholm. 1996. Corporate disclosure policy and analyst behavior. The Accounting Review 71 (4): 467-492.

Lee, P.M., and E.H. James. 2007. She'-e-os: Gender effects and investor reactions to the announcements of top executive appointments. Strategic Management Journal 28 (3): 227-241.

Lee, S., S. Matsunaga, and C. Park. 2012. Management forecast accuracy and CEO turnover. Accounting Review 87: 2095-2122.

Li, F. 2008. Annual report readability, current earnings, and earnings persistence. Journal of Accounting and Economics 45: 221-247.

Lonkani, R. 2019. Gender differences and managerial earnings forecast bias: Are female executives less overconfident than male executives? Emerging Markets Review 38: 18-34.

Loughran, T., and B. McDonald. 2014. Measuring readability in financial disclosures. The Journal of Finance 69 (4): 1643-1671.

Loughran, T. and B. McDonald. 2016. Textual analysis in accounting and finance: A survey. Journal of Accounting Research 54 (4):1187-1230.

Lund, D.B. 2008. Gender differences in ethics judgment of marketing professionals in the United States. Journal of Business Ethics 77 (4): 501-515.

Matsumoto, D. 2002. Management's incentives to avoid negative earnings surprises. The Accounting Review 77: 483-514.

McDonald, M., G. Keeves, and J. Westphal. 2018. One step forward, one step back: White male top manager organizational identification and helping behavior toward other executives following the appointment of a female or racial minority CEO. Academy of Management Journal 61 (2): 405-439.

McLaughlin, G.H. 1969. SMOG grading: A new readability formula. Journal of Reading 12: 639-646.

Mikhail, M.B., B.R. Walther, and R.H. Willis. 1999. Does forecast accuracy matter to security analysts? The Accounting Review 74 (2): 185-200.

Na, K., and J. Hong. 2017. CEO gender and earnings management. Journal of Applied Business Research 33 (2): 297-308.

Nagar, V., D. Nanda, and P. Wysocki. 2003. Discretionary disclosure and stock-based incentives. Journal of Accounting and Economics 34: 283-309.

Nalikka, A. 2009. Impact of gender diversity on voluntary disclosure in annual reports. Accounting \& Taxation 1 (1): 101-113.

Nesbitt, P. 1997. Gender, tokenism and the construction of elite clergy careers. Review of Religious Research 38 (3): 193-210.

Ng, J., I. Tuna, and R. Verdi. 2013. Management forecast credibility and underreaction to news. Review of Accounting Studies 18: 956-986.

Niessen-Ruenzi, A., and S. Ruenzi. 2019. Sex matters: Gender bias in the mutual fund industry. Management Science 65 (7): 3001-3025.

Oakley, J.G. 2000. Gender-based barriers to senior management positions: Understanding the scarcity of female CEOs. Journal of Business Ethics 27 (4): 321-334.

Offermann, L.R., and C. Beil. 1992. Achievement styles of women leaders and their peers: Toward an understanding of women and leadership. Psychology of Women Quarterly 16 (1): 37-56.

Patell, J.M. 1976. Corporate forecasts of earnings per share and stock price behavior: Empirical tests. Journal of Accounting Research 14 (2): 246-276.

Penman, S.H. 1980. An empirical investigation of the voluntary disclosure of corporate earnings forecasts. Journal of Accounting Research 18 (1): 132-160. 
Pew Research Center. (2018). Few Women Lead Large U.S. Companies, Despite Modest Gains over Past Decade. https://www.pewresearch.org/fact-tank/2018/09/26/few-women-lead-large-u-s-companiesdespite-modest-gains-over-past-decade/

Rajgopal, S., T. Shevlin, and V. Zamora. 2006. CEOs' outside employment opportunities and the lack of relative performance evaluation in compensation contracts. The Journal of Finance 61 (4): 1813-1844.

Rosener, JB. 1990. Ways Women Lead. Harvard Business Review 68 (6):119-125.

Roychowdhury, S. 2006. Earnings management through real activities manipulation. Journal of Accounting and Economics 42 (3): 335-370.

Ryan, M.K., and S.A. Haslam. 2007. The glass cliff: Exploring the dynamics surrounding the appointment of women to precarious leadership positions. Academy of Management Review 32 (2): 549-572.

Securities and Exchange Commission (SEC). (1998). A plain English handbook. SEC Office of Investor Education and Assistance. Washington D.C.: SEC. Available at: https://www.sec.gov/reportspubs/ investor-publications/newsextrahandbookhtm.html.

Securities and Exchange Commission (SEC). (2000). Final Rule: Rulemaking for EDGAR System. Available at: https://www.sec.gov/rules/final/33-7855.htm.

Skinner, D.J. 1994. Why firms voluntarily disclose bad news. Journal of Accounting Research 32 (1): 38-60.

Tan, H., R. Libby, and J. Hunton. 2002. Analysts' reactions to earnings preannouncement strategies. Journal of Accounting Research 40: 223-246.

Valentine, S.R., and T.L. Rittenburg. 2004. Spanish and American business professionals' ethical evaluations in global situations. Journal of Business Ethics 51 (1): 1-14.

Valentine, S., and R. Kidwell. 2008. Business students' ethical evaluations of faculty misconduct. Quality Assurance in Education 16 (3): 287-300

Waymire, G. 1985. Earnings volatility and voluntary management forecast disclosure. Journal of Accounting Research 23 (1): 268-295.

Weeks, W.A., C.W. Moore, J.A. McKinney, and J.G. Longenecker. 1999. The effects of gender and career stage on ethical judgment. Journal of Business Ethics 20 (4): 301-331.

Williams, P.A. 1996. The relation between a prior earnings forecast by management and analyst response to a current management forecast. The Accounting Review 71 (1): 103-115.

Zmijewski, M.E. 1984. Methodological issues related to the estimation of financial distress prediction models. Journal of Accounting Research 22: 59-82.

Publisher's note Springer Nature remains neutral with regard to jurisdictional claims in published maps and institutional affiliations.

\section{Affiliations}

\section{Claude Francoeur ${ }^{1} \cdot$ Yuntian $^{\mathrm{Li}^{1}} \cdot$ Zvi Singer $^{1} \cdot$ Jing Zhang ${ }^{2}$}

1 HEC Montréal, 3000 Chemin de la Côte-Sainte-Catherine, Montréal, Québec, Canada

2 The CU Denver Business School, University of Colorado, 1475 Lawrence St, Denver, CO, USA 